\title{
De arbeidsmarkt naar opleiding en beroep in 1992
}

Citation for published version (APA):

de Grip, A., Heijke, J. A. M., \& Dekker, R. (1989). De arbeidsmarkt naar opleiding en beroep in 1992.

Researchcentrum voor Onderwijs en Arbeidsmarkt, Faculteit der Economische Wetenschappen. ROA Reports No. 8 https://doi.org/10.26481/umarep.1989008

Document status and date:

Published: 01/01/1989

DOI:

10.26481/umarep.1989008

Document Version:

Publisher's PDF, also known as Version of record

\section{Please check the document version of this publication:}

- A submitted manuscript is the version of the article upon submission and before peer-review. There can be important differences between the submitted version and the official published version of record.

People interested in the research are advised to contact the author for the final version of the publication, or visit the DOI to the publisher's website.

- The final author version and the galley proof are versions of the publication after peer review.

- The final published version features the final layout of the paper including the volume, issue and page numbers.

Link to publication

\footnotetext{
General rights rights.

- You may freely distribute the URL identifying the publication in the public portal. please follow below link for the End User Agreement:

www.umlib.nl/taverne-license

Take down policy

If you believe that this document breaches copyright please contact us at:

repository@maastrichtuniversity.nl

providing details and we will investigate your claim.
}

Copyright and moral rights for the publications made accessible in the public portal are retained by the authors and/or other copyright owners and it is a condition of accessing publications that users recognise and abide by the legal requirements associated with these

- Users may download and print one copy of any publication from the public portal for the purpose of private study or research.

- You may not further distribute the material or use it for any profit-making activity or commercial gain

If the publication is distributed under the terms of Article $25 \mathrm{fa}$ of the Dutch Copyright Act, indicated by the "Taverne" license above, 
De arbeidsmarkt naar opleiding en

beroep in 1992

ROA-R-1989/8 
DE ARBEIDSMARKT NAAR OPLEIDING EN BEROEP IN 1992

ROA-R-1989/8

A. de Grip

J.A.M. Heijke

R.J.P. Dekker

RESEARCHCENTRUM VOOR ONDERWIJS EN ARBEIDSMARKT

Faculteit der Economische Wetenschappen

Rijksuniversiteit Limburg

Maastricht, december 1989 
GEGEVENS KONINKLIJKE BIBLIOTHEEK, DEN HAAG

Grip, A. de

De arbeidsmarkt naar opleiding en beroep in 1992/ A. de Grip, J.A.M. Heijke, R.J.P. Dekker. -

Maastricht: Researchcentrum voor Onderwijs en Arbeidsmarkt, Faculteit der Economische Wetenschappen, Rijksuniversiteit Limburg. - Ill. - (Rapport/ Researchcentrum voor Onderwijs en Arbeidsmarkt ; 1989/8 met 1it. opg.

ISBN 90-5321-025-3

SISO 318.7 UDC $331.5+37(492) " 313 "$

Trefw.: arbeidsmarkt; Nederland; toekomst / onderwijs en arbeidsmarkt; Nederland; toekomst. 
Niets uit deze uitgave mag worden verveelvoudigd en/of openbaar gemaakt door middel van druk, fotocopie, microfilm, of op welke andere wijze ook, zonder voorafgaande schriftelijke toestemming van de directeur van het Researchcentrum voor Onderwijs en Arbeidsmarkt. In geval van overname van het data-materiaal moet telkens als bronvermelding worden vermeld: "Researchcentrum voor Onderwijs en Arbeidsmarkt" of "ROA". 
2. PROGNOSES WERKGELEGENHEIDSONTWIKKELING

2.2. Werkgelegenheidsontwikkeling naar bedrijfssector

2.3. Werkgelegenheidsontwikkeling naar beroepsklasse

2.4. Werkgelegenheidsontwikkeling naar opleidingstype

3. PROGNOSES VERVANGINGSVRAAG

3.1. Inleiding 14

3.2. Vervangingsvraag naar beroepsklasse 14

3.3. Vervangingsvraag naar opleidingstype 20

4. PROGNOSE INSTROOM VAN SCHOOLVERLATERS 22

4.1. Inleiding 22

4.2. Methode 22

4.3. Resultaten 25

5. JOB OPENINGS EN ARBEIDSMARKTPERSPECTIEVEN 27

$\begin{array}{ll}\text { 5.1. Inleiding } & 27\end{array}$

5.2. Job openings 27

5.3. Arbeidsmarktperspectieven naar opleidingstype 28

6. RISICO-INDICATOREN

6.1. Inleiding 33

6.2. Conjunctuurgevoeligheid 33

6.3. Uitwijkmogelijkheden 35

$\begin{array}{lr}\text { 7. BESLUIT } & 41\end{array}$

$\begin{array}{lr}\text { LITERATUUR } & 43\end{array}$

BIJLAGE 1: Totaaloverzicht van de conjunctuurgevoeligheid per beroepsklasse (fluctuatie-index FI)

BIJLAGE 2: Totaaloverzicht van de bedrijfssectorspreiding per beroepsklasse (Gini-Hirschman coëfficiënt GH) 
BIJLAGE 3: Totaaloverzicht van de beroepsklassespreiding per opleidingstype (Gini-Hirschman coëfficiënt GH)

BIJLAGE 4: Totaaloverzicht van de bedrijfssectorspreiding per opleidingstype (Gini-Hirschman coëfficiënt $\mathrm{GH}$ ) 
VERANTWOORDING

Het onderzoek waarover hier wordt gerapporteerd is uitgevoerd in het kader van een meerjarige onderzoeksopdracht van het Ministerie van Onderwijs en Wetenschappen. Deze opdracht betreft de ontwikkeling van een informatiesysteem onderwijsarbeidsmarkt, dat bruikbaar is voor de studie- en beroepskeuze. Het onderzoek is mede mogelijk gemaakt door een aanvullende onderzoeksopdracht in het kader van het I-See! project, waarvan de projectorganisatie in handen is van het Landelijk Dienstverlenend Centrum i.o.

Het I-See! project betreft de ontwikkeling van een interactief te raadplegen studie- en beroepskeuzesysteem, waarbij beroepen-, opleidingen- en arbeidsmarktinformatie in één geautomatiseerd systeem zijn ondergebracht. Het I-See! produkt, een CD-ROM, komt begin 1990 op de markt en is in een eerste aanzet gericht op de intermediairs bij de keuze van studie of beroep (decanen, studie- en beroepskeuzeadviseurs en arbeidsbureaus). Het ROA heeft de gegevens verschaft ten behoeve van de zogenaamde arbeidsmarktmodule van I-See! (De Grip, Heijke, Dekker, Beekman en Peeters, 1989)

Het onderzoek stond onder leiding van prof. dr. J.A.M. Heijke, directeur van het ROA. De dagelijkse leiding berustte bij dr. A. de Grip. Aan het onderzoek is meegewerkt door drs. R.J.P. Dekker, drs. Th.B.J. Beekman en drs. H.M.M. Peeters. M.H. Wieling verleende assistentie bij de verwerking en analyse van het datamateriaal. 


\section{INLEIDING}

Het ROA-informatiesysteem onderwijs-arbeidsmarkt heeft vooralsnog primair als doel informatie te genereren die bruikbaar is voor de studie- en beroepskeuze. Daarnaast zou dit ROA-informatiesysteem echter in principe ook van nut kunnen zijn voor de capaciteitsplanning in het onderwijs, het arbeidsvoorzieningsbeleid, het economische structuur- en technologiebeleid en het personeelsbeleid van zowel overheid als bedrijfsleven.

Dit rapport vormt de verslaglegging van de stand van zaken met betrekking tot de bouw van het informatiesysteem. In vergelijking met de vorige rapportage (De Grip, Heijke, Dekker en Groot, 1987) wordt nu voor de eerste maal informatie over de volle breedte van het onderwijs gegenereerd. Ook heeft een verdere uitbouw van de prognosemodellen plaats gevonden. De komende jaren zal worden gewerkt aan een verdere ontwikkeling van het informatiesysteem. Daarbij gaat het zowel om een verdere verbetering van de prognosemodellen, als om de actualisering en uitbouw van de statistische basisgegevens. Ook zal worden bekeken of er andere, nog niet in het informatiesysteem opgenomen arbeidsmarktindicatoren relevant zijn voor de studie- en beroepskeuze (en andere doelgroepen) en zal worden onderzocht in hoeverre het mogelijk is de arbeidsmarktinformatie te regionaliseren. Het is de bedoeling dat elke twee jaar een rapport met nieuwe prognoses wordt uitgebracht.

Dit rapport is toegespitst op de twee belangrijkste componenten van het huidige ROAinformatiesysteem: de middellange-termijn prognoses van de arbeidsmarktperspectieven en de zogenaamde 'risico-indicatoren' met betrekking tot opleidingen en beroepen'. Bovendien wordt in dit rapport een cijfermatige onderbouwing gegeven van de kwalitatieve typeringen van de arbeidsmarktperspectieven en risico-indicatoren, zoals die bij I-See! op het beeldscherm te zien zijn. Deze cijfermatige onderbouwing is bewust niet op beeldscherm te zien, vanwege het gevaar dat gebruikers te veel waarde zouden kunnen hechten aan de exacte uitkomsten van de prognoses, e.d. Dit zou niet terecht zijn, gezien de onzekerheidsmarges waaraan dergelijke voorspellingen onderhevig zijn. Dat deze cijfers in dit rapport wel worden vermeld, heeft slechts als doel een verantwoording te geven van de door ons opgeleverde arbeidsmarktprognoses en risico-indicatoren.

In de jaren tachtig kan worden waargenomen dat de aandacht voor de rol van

1. In I-See! worden daarnaast nog een groot aantal historische data gegeven. Voor de toepassing van historische data in een informatiesysteem onderwijs-arbeidsmarkt moet derhalve worden verwezen naar het I-See! produkt. 
arbeidsmarktfactoren op de schoolkeuze groter is geworden. Naast overheidscampagnes om de keuze van een exacte of technische richting of een beroepsopleiding te bevorderen, hebben ook banenplannen en omscholingsprojecten in de jaren '80 een belangrijke schaalvergroting te zien gegeven. Deze arbeidsmarktinstrumenten kunnen worden gezien als een vorm van curatief beleid (De Grip 1987), dat is gericht op het achteraf corrigeren van reeds opgetreden discrepanties tussen vraag en aanbod op de arbeidsmarkt. Essentieel voor een goede kwalitatieve aansluiting tussen vraag en aanbod op de arbeidsmarkt is echter het voeren van een preventief beleid, waarbinnen een goede informatievoorziening over de arbeidsmarktperspectieven van opleidingen en beroepen een belangrijke plaats zou moeten innemen. Daarbij komt de vraag naar voren welke informatie nodig is om vraagtekorten of aanbodoverschotten op de arbeidsmarkt te voorkomen, of te dempen. Het gevaar van het optreden van zogenaamde varkenscycli op de arbeidsmarkt is immers aanwezig als men zich bij de studiekeuze volledig zou baseren op de actuele situatie op de arbeidsmarkt in plaats van op de reële perspectieven op de middellange termijn.

Men is er zich momenteel echter ook terdege van bewust dat de stuurbaarheid van de arbeidsmarkt niet zo sterk is als men ten tijde van de populariteit van de zogenaamde 'manpowerplanning' in de jaren zestig aannam. Vooral de onderliggende veronderstellingen zoals de direkte koppeling tussen een bepaalde opleiding en een bepaald beroep en de absolute betekenis die aan arbeidsmarktprognoses werd gehecht leverden praktische problemen op. De huidige tendens is dat er econometrisch meer consistente modellen worden geconstrueerd en dat er bijvoorbeeld ook beter rekening wordt gehouden met het feit dat de opleidingenstructuur van een beroep en een bedrijfssector kan veranderen in de tijd. Tevens geldt echter voor de meer globale prognoses van het Centraal Planbureau dat het hoge aggregatieniveau van de onderscheiden opleidingscategorieën en het ontbreken van gegevens over beroepen de prognoses weinig bruikbaar maken voor studie- en beroepskeuzebeslissingen.

Het ROA-informatiesysteem onderwijs-arbeidsmarkt onderscheidt opleidingen en beroepen op een aanzienlijk lager aggregatieniveau. Een verdergaande desaggregatie vergroot echter ook de kans dat de prognoses niet overeenkomen met de realisaties. Op een hoog aggregatieniveau speelt een deel van de verschuivingen in de opleidingen- en beroepenstructuur zich immers binnen de onderscheiden classificaties af. Bovendien is de mogelijkheid dan groter dat eventuele voorspelfouten elkaar compenseren. Met de grotere foutenmarges van de uitkomsten van de prognoses wordt rekening gehouden door in het geautomatiseerde informatiesysteem voor de studie- en beroepskeuze I-See!, waarvoor het ROA zoals gezegd de arbeidsmarktgegevens heeft verschaft, geen 'exacte' puntvoorspellingen van de toekomstige situatie op de 
arbeidsmarkt te presenteren, maar slechts indicatieve kwalitatieve aanduidingen te geven. Ons inziens is een dergelijke kwalitatieve typering van de arbeidsmarktperspectieven van opleidingen en beroepen toereikend voor het beoogde doel: bij studieen beroepskeuzebeslissingen de arbeidsmarktperspectieven van opleidingen en beroepen in ogenschouw nemen.

De middellange-termijn prognoses voor de beroepen bestaan uit een tweetal componenten:

- de verwachte uitbreidingsvraag (de werkgelegenheidsontwikkeling);

- de verwachte vervangingsvraag.

Op deze wijze wordt een beeld verkregen van de verwachte zogenaamde 'job openings' in de verschillende beroepsklassen.

Bij de prognoses van de arbeidsmarktperspectieven voor de verschillende opleidingstypen wordt het aantal geprognosticeerde 'job openings' (uitbreidings- en vervangingsvraag) afgezet tegen de verwachte potentiële instroom van schoolverlaters/afgestudeerden op de arbeidsmarkt. Op deze wijze wordt een kwalitatieve typering van de arbeidsmarktperspectieven van de desbetreffende opleiding afgeleid. Hierbij wordt geen rekening gehouden met de omvang van de huidige werkloosheid, onder andere omdat onduidelijk is in hoeverre deze werkloosheid daadwerkelijk van invloed is op de arbeidsmarktperspectieven van recent afgestudeerde schoolverlaters.

De opgestelde toekomstverwachtingen worden aangevuld met arbeidsmarktindicatoren, die informatie geven over de huidige arbeidsmarktsituatie en over de risico's die men met een bepaalde opleidings- of beroepskeuze loopt. Deze zogenaamde 'risicoindicatoren' betreffen de conjunctuurgevoeligheid van de werkgelegenheid en de uitwijkmogelijkheden naar andere beroepen of bedrijfssectoren. Voordeel van deze aanpak is dat de arbeidsmarktprognoses in samenhang met andere arbeidsmarktaspecten van beroepen en opleidingen kunnen worden afgewogen.

De prognoses hebben betrekking op de periode 1985-1992. Het jaar 1985 vormt het basisjaar, omdat dit helaas momenteel het laatste jaar is waarvoor gedetailleerde historische gegevens over de arbeidsmarkt bekend zijn. De prognoses richten zich op de middellange termijn. Hiervoor is gekozen omdat dan rekening kan worden gehouden met de situatie op de arbeidsmarkt ten tijde van het afstuderen. Anderzijds is de prognoseperiode niet zo lang, dat de onzekerheid omtrent de prognoses onaanvaardbaar groot zou worden. Ten tijde van het doorrekenen van de prognosemodellen waren er nog geen CPB-prognoses naar bedrijfssector van het jaar 1994 voorhanden, zodat vooralsnog moet worden volstaan met een prognose voor het jaar 1992. 
Er worden in het ROA-informatiesysteem 23 bedrijfstakken, 79 beroepsklassen en 53 opleidingstypen onderscheiden. De bedrijfstakken zijn gebaseerd op de indeling die het Centraal Planbureau hanteert in het Centraal Economisch Plan. De beroepsklassen komen overeen met het 2-digit niveau van de beroepenclassificatie van het Centraal Bureau voor de Statistiek. Het totale onderwijs is op basis van de Standaard Onderwijs Indeling (3-cijfer-code) verdeeld in 53, voor de arbeidsmarkt relevante, opleidingstypen. Op deze wijze wordt het mogelijk een gedifferentieerd overzicht van de verwachte ontwikkelingen op de arbeidsmarkt te geven.

Vanuit het oogpunt van de aansluitingsproblematiek tussen onderwijs en arbeidsmarkt is de huidige indeling in beroepsklassen niet optimaal (bv. verplegenden en artsen zijn in dezelfde beroepsklasse ingedeeld). Binnen het ROA is reeds onderzoek uitgevoerd naar de mogelijkheid om een alternatieve indeling te maken die leidt tot een grotere homogeniteit van de beroepsklassen met betrekking tot de vereiste opleiding (De Grip, Groot en Heijke, 1987). Deze nieuwe beroepsklasse-indeling is samengesteld op basis van de meer gedetailleerde beroepsgroepenindeling (ongeveer 320 beroepsgroepen). De onzekerheid over de beschikbaarheid van gegevens op dit aggregatieniveau in de toekomst leidt echter tot een vooralsnog behoudende aanpak met betrekking tot de te hanteren beroepenclassificatie.

De verdere opzet van dit rapport is als volgt. In hoofdstuk 2 wordt ingegaan op de werkgelegenheidsprognoses naar bedrijfssector (paragraaf 2.2.), beroepsklasse (paragraaf 2.3.) en opleidingstype (paragraaf 2.4.). In hoofdstuk 3 wordt de vervangingsvraag naar beroepsklasse en opleidingstype uitgewerkt. Hoofdstuk 4 vervolgt met de prognose van de verwachte potentiële instroom van schoolverlaters op de arbeidsmarkt. In hoofdstuk 5 vindt een confrontatie plaats tussen de instroom van schoolverlaters en de totale vraag naar arbeid per opleidingstype. In hoofdstuk 6 wordt ingegaan op de verschillende risico-indicatoren. Hoofdstuk 7 besluit met de stand van zaken van het informatiesysteem onderwijs-arbeidsmarkt van het ROA en de mogelijke verdere ontwikkelingen daarvan. 


\section{PROGNOSES WERKGELEGENHEIDSONTWIKKELING}

\subsection{Inleiding}

Bij het maken van werkgelegenheidsprognoses voor de periode 1985 -'92 wordt voortgebouwd op de werkgelegenheidsraming in arbeidsjaren per bedrijfssector van het Centraal Planbureau. De werkgelegenheid in arbeidsjaren wordt eerst, via de personen-arbeidsjaren ( $\mathrm{P} / \mathrm{A}$ ) ratio, omgerekend naar werkzame personen. De werkzame personen per bedrijfssector worden vervolgens verdeeld over de 79 onderscheiden beroepsklassen. Tenslotte wordt, rekening houdend met de verwachte verschuivingen in de bedrijfssector- en beroepsklassestructuur, de werkgelegenheidsprognose voor 53 opleidingstypen bepaald. Hierbij wordt onderscheid gemaakt tussen opleidingsniveau en -richting. De aanpak om eerst het aantal werkzame personen per bedrijfssector te prognosticeren en deze vervolgens te verdelen over beroepen en opleidingen, waarborgt de consistentie tussen de verschillende prognoses. In de volgende paragrafen wordt nader ingegaan op de prognoses en de achterliggende modellen.

\subsection{Werkgelegenheidsontwikkeling naar bedrijfssector}

Voor de sectorale prognoses wordt aansluiting gezocht bij de middellange-termijn raming van het Centraal Planbureau. Hierin wordt een prognose gegeven van het arbeidsvolume $^{2}$ (in mensjaren) tot en met 1990 naar bedrijfssector volgens een sectorindeling die gekoppeld kan worden aan de 23 bedrijfssectoren die in het ROAinformatiesysteem worden onderscheiden. Vervolgens wordt een prognose gemaakt van de ontwikkeling van deeltijdarbeid, e.d. op basis van de P/A ratio's van de verschillende bedrijfssectoren, zodat de geprognosticeerde werkgelegenheid in mensjaren kan worden omgezet in werkzame personen. Voor deze P/A ratio's zijn slechts prognoses beschikbaar op een hoger aggregatieniveau. Verder geldt voor zowel het arbeidsvolume als de P/A ratio dat de CPB-prognose slechts tot 1990100 t. Bijgevolg dient de werkgelegenheid en de P/A ratio voor 1991 en 1992 door het ROA te worden geprognosticeerd. Dit is gebeurd op basis van de gemiddelde groei van de respectievelijke grootheden over de periode 1985-1990.

In tabel 1 wordt een overzicht gegeven van de prognose van de werkgelegenheid in werkzame personen. De verwachting is dat de totale werkgelegenheid in 1992 met $10 \%$ toeneemt ten opzichte van 1985. Vergelijken we dit met de vorige prognose (De Grip, Heijke, Dekker en Groot 1987, pag. 11) dan zien we dat de gemiddelde verwachte

2. Centraal Economisch Plan 1989, bijlage D (diskette). 
werkgelegenheidsgroei niet is veranderd. Er zijn echter wel verschillen voor de afzonderlijke bedrijfssectoren waar te nemen. Deze verschillen kunnen voor een groot deel worden verklaard uit de recente bijstellingen door het Centraal Planbureau van het arbeidsvolume per bedrijfssector tot 1990 .

Tabel 1. Werkzame personen (x 1.000) naar bedrijfssector in 1992

\begin{tabular}{|c|c|c|c|}
\hline & $\begin{array}{c}\text { Werkzame } \\
\text { personen } \\
1985 \\
\end{array}$ & $\begin{array}{c}\text { Werkzame } \\
\text { personen } \\
1992 \\
\end{array}$ & $\begin{array}{l}\% \text { mutatie } \\
1985-' 92\end{array}$ \\
\hline 1 Landbouw, visserij en bosbouw & 268.1 & 266.4 & -0.6 \\
\hline 2. Voedings- en genotmiddelenindustrie & 165.9 & 172.2 & 3.8 \\
\hline 3. Textiel, kleding-, en leder- en schoenindustrie & 55.6 & 58.2 & 4.7 \\
\hline 4. Hout- en bouwmaterialenindustrie & 72.9 & 79.0 & 8.3 \\
\hline 5. Papier- en grafische industrie & 114.5 & 132.4 & 15.6 \\
\hline 6. Chemische, rubber-en kunststof-verwerkende industrie & 115.5 & 133.7 & 15.8 \\
\hline 7. Basismetaalindustrie & 33.3 & 34.6 & 3.8 \\
\hline 8. Metaalprodukten- en optische industrie & 254.0 & 281.2 & 10.7 \\
\hline 9. Electrotechnische industrie & 100.7 & 106.7 & 5.4 \\
\hline 10. Transportmiddelenindustrie & 71.0 & 73.0 & 2.8 \\
\hline 11. Aardolie-industrie & 9.5 & 9.9 & 3.8 \\
\hline 12. Delfstoffenwinning & 11.4 & 12.3 & 7.9 \\
\hline 13. Openbare nutsbedrijven & 44.1 & 45.7 & 3.6 \\
\hline 14. Bouwnijverheid & 385.7 & 411.0 & 6.6 \\
\hline 15. Woningbezit & 30.8 & 36.6 & 18.8 \\
\hline 16. Handel & 720.0 & 861.6 & 19.7 \\
\hline 17. Zee- en luchtvaart & 51.0 & 59.6 & 16.9 \\
\hline 18. Overige transport-, opslag- en communicatiebedrijven & 271.7 & 311.6 & 14.7 \\
\hline 19. Bank- en verzekeringswezen & 185.9 & 207.3 & 11.5 \\
\hline 20. Overige tertiaire diensten & 560.9 & 666.1 & 18.8 \\
\hline 21. Medische en veterinaire diensten & 374.7 & 422.9 & 12.9 \\
\hline 22. Overige kwartaire diensten & 426.6 & 473.7 & 11.0 \\
\hline 23. Overheid ${ }^{*}$ & 780.5 & 809.0 & 3.7 \\
\hline Totaal & 5143.4 & 5664.4 & 10.1 \\
\hline
\end{tabular}

Bron: $\mathrm{CPB} / \mathrm{ROA}$

\subsection{Werkgelegenheidsontwikkeling naar beroepsklasse}

De sectorprognoses vormen het uitgangspunt voor de prognose van de uitbreidingsvraag per beroepsklasse. Uit de Arbeidskrachtentellingen zijn tweejaarlijkse gegevens beschikbaar van de verdeling van de werkzame personen per beroepsklasse over de bedrijfssectoren over de periode 1975-1985. In Dekker, De Grip en Heijke (1988) is een aanvang gemaakt met een economische verklaring van de beroepenstructuur naar bedrijfstak. Naast de technologische ontwikkeling (investeringen, automatisering) worden ook conjuncturele factoren (bezettingsgraad) en structurele (trend)effecten in het model opgenomen. Uitgangspunt vormt de schatting van het 
aandeel van beroep $b$ in de werkgelegenheid van sector s. Verder wordt er rekening gehouden met de ontwikkeling van de gemiddelde arbeidsduur per beroep en per sector. Dit laatste is noodzakelijk om de koppeling te kunnen maken tussen werkzame personen (de te verklaren variabele) en de regressoren die het effect op het arbeidsvolume weerspiegelen. Vanwege de beperkte periode waarover de gegevens beschikbaar zijn, zijn de data per beroepsklasse gepooled over de verschillende sectoren om zodoende per uitgevoerde schatting meer data (en daarmee vrijheidsgraden) te verkrijgen. Daarbij zijn de sectoren in twee hoofdgroepen verdeeld: landbouw en industrie versus de dienstensector. Per zogenaamde hoofdgroep worden dan de parameters van de exogenen gelijk gesteld voor alle sectoren. Per beroep wordt dan de volgende vergelijking geschat:

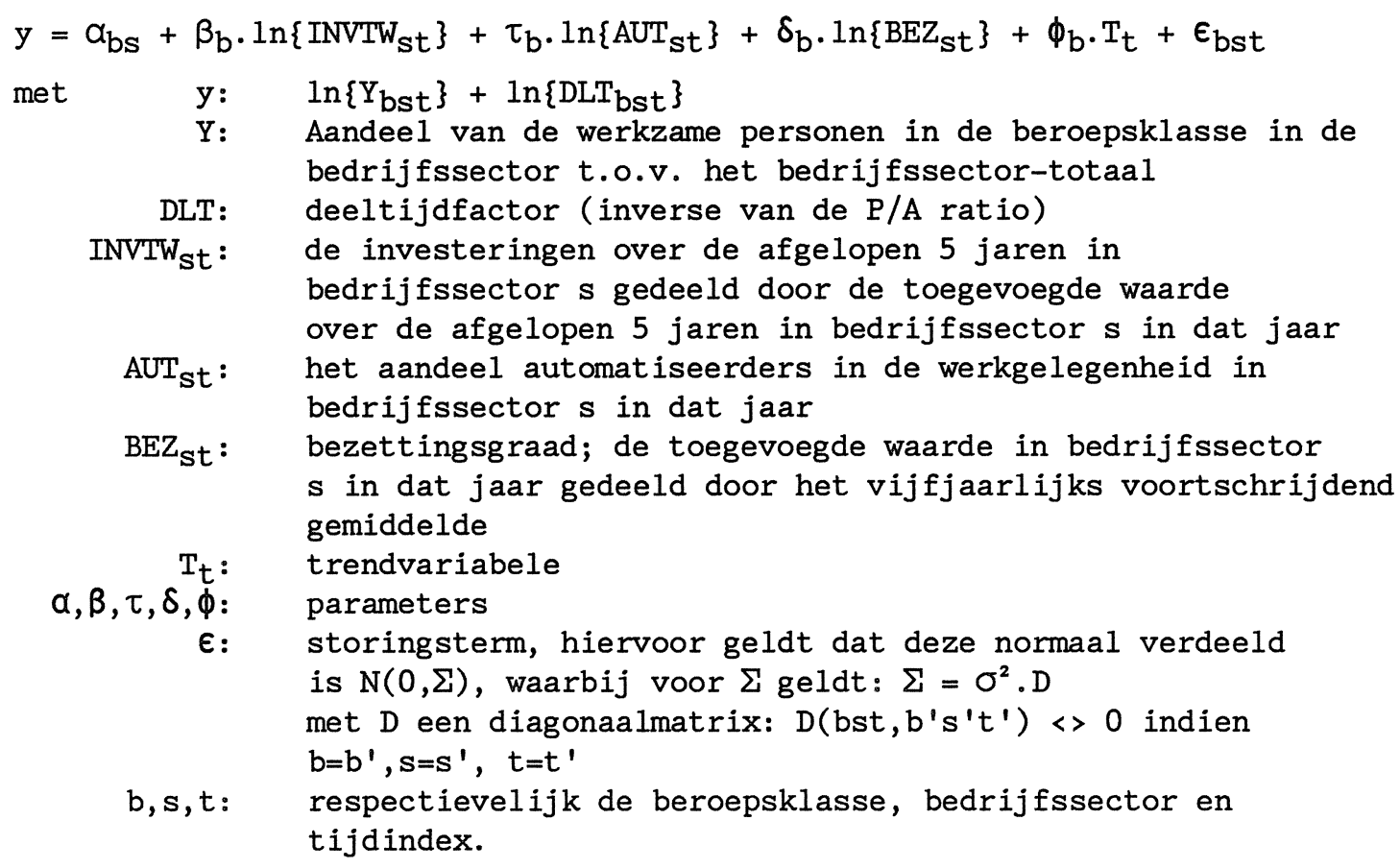

Als bij het schatten van dit model alleen de sectorconstante significant zou zijn, impliceert dit dat het aandeel van een beroep in een sector constant is. De investeringen gerelateerd aan de toegevoegde waarde en het aandeel van automatiseerders in een sector vormen een indicatie voor de technologische ontwikkeling (zie Dekker, De Grip en Heijke 1988). De bezettingsgraad is benaderd door de toegevoegde waarde in het huidige jaar te relateren aan het vijfjaarlijks voortschrijdende gemiddelde van de toegevoegde waarde. De trend is exponentieel opgenomen, wat de interpretatie van de parameter vergemakkelijkt. Nadeel hiervan is echter dat de trend zou kunnen 'exploderen'. Vandaar dat in de modelselectie eerst wordt getoetst of de trend significant is. Wordt deze toets verworpen dan volgt een toets op het significant zijn van de verklarende variabelen (dus exclusief trend) ten opzichte van het model met alleen sectorconstanten. 
$-8-$

Bij het schatten van de werkgelegenheidsaandelen wordt geen informatie meegenomen over de absolute aantallen werkzame personen in een beroep in een sector. Dit kan worden ondervangen door de vergelijkingen te schatten met behulp van gewogen kleinste kwadraten (Weighted Least Squares), waarbij de aandelen gewogen worden met het aantal werkzame personen in het beroep in de sector. Deze weging impliceert dat aandelen die een groot aantal werkzame personen representeren een groter gewicht in de bepaling van de parameters krijgen toebedeeld. Bijkomend voordeel is dat de weging ook corrigeert voor de heteroscedasticiteit, vanwege het feit dat bij kleine aantallen de meetfouten relatief groot kunnen zijn.

Voor de uitkomsten van de schattingen verwijzen we naar het eerder genoemde werkdocument van Dekker, de Grip en Heijke (1988). Op deze plaats zullen we alleen stilstaan bij de resultaten van het doorrekenen van het model voor 1992 .

In de tabellen $2 a$ en $2 b$ zijn respectievelijk de sterk groeiende en de sterk dalende beroepen weergegeven. Als de sterk dalende beroepen worden geconfronteerd met de sterk stijgende beroepen, dan blijkt dat in de eerste groep veel traditionele industrie-beroepen zitten. Bij de dalende beroepen vinden we ook een aantal kleine beroepen. Hiervoor geldt enige terughoudendheid vanwege het feit dat de gegevens gebaseerd zijn op een steekproef en omdat de meetfouten voor kleine beroepen grotere gevolgen hebben op veranderingen in het aantal werkzame personen dan bij grote beroepen. Ook leidt bij kleine beroepen een absolute verandering eerder tot een enorme procentuele toe- of afname.

Bij de stijgers komen naast de medische beroepen met name beroepen in de dienstverlenende sfeer voor, waarbij beroepen met relatief lage opleidingseisen (winkelbedienden, schoonmaakpersoneel) in absolute aantallen sterk vertegenwoordigd zijn. Van de totale toename van de werkgelegenheid van ongeveer 600.000 personen (zie tabel 1) nemen deze twee beroepsklassen samen een zesde deel voor hun rekening.

\subsection{Werkgelegenheidsontwikkeling naar opleidingstype}

De prognose van de werkgelegenheid per bedrijfssector en het aandeel van een beroepsklasse in een sector vormen het uitgangspunt voor de prognose van de werkgelegenheid per opleidingstype. Als we immers het aandeel van een opleidingstype voor elke sector-beroepcombinatie schatten dan kan hieruit de werkgelegenheid per opleidingstype worden afgeleid, rekening houdend met verschuivingen in de sector- en beroepenstructuur. Het opleidingenmodel verklaart additioneel hieraan de verschuivingen in de opleidingsaandelen binnen de verschillende beroepsklassen. 
Tabel 2a. Sterk groeiende beroepsklassen 1985-1992

\begin{tabular}{llccc}
\hline code & beroepsklasse & $\begin{array}{c}\text { aantal } \\
\text { werkenden } \\
1985\end{array}$ & $\begin{array}{c}\text { aantal } \\
\text { werkenden } \\
1992\end{array}$ & $\begin{array}{c}\% \\
\text { groei }\end{array}$ \\
\hline & & & & \\
08 & Wiskundigen, systeemanalisten e.d. & 50.700 & 95.200 & 88 \\
55 & Huisbewaarders en schoonmaakpersoneel & 139.500 & 192.200 & 38 \\
50 & Directeuren en bedrijfsleiders horecabedrijven & 13.200 & 16.600 & 26 \\
32 & Secretaresses, (data)typistes e.d. & 148.100 & 185.700 & 25 \\
48 & Winkelbedienden, marktverkopers e.d. & 251.000 & 313.400 & 25 \\
85 & Electromonteurs, -reparateurs & 111.100 & 138.200 & 24 \\
34 & Computerapparatuur-operateurs e.d. & 11.500 & 14.100 & 23 \\
47 & Verzekeringsagenten, makelaars e.d. & 34.300 & 42.200 & 23 \\
30 & Leidinggevend administratief personeel & 17.600 & 21.500 & 22 \\
06 & Medisch- en paramedisch personeel & 267.500 & 324.800 & 21 \\
& & & & \\
\hline
\end{tabular}

Bron: ROA

Tabel 2b. Sterk dalende beroepsklassen 1985-1992

\begin{tabular}{|c|c|c|c|c|}
\hline code & beroepsklasse & $\begin{array}{c}\text { aantal } \\
\text { werkenden } \\
1985\end{array}$ & $\begin{array}{c}\text { aantal } \\
\text { werkenden } \\
1992\end{array}$ & $\begin{array}{c}\% \\
\text { afname }\end{array}$ \\
\hline 96 & Machinisten e.a. bedieners van machines & 6.000 & 3.500 & -42 \\
\hline 73 & Houtzagers, papiermakers & 7.200 & 5.200 & -28 \\
\hline 83 & Smeden, gereedschapsmakers e.d. & 40.500 & 32.200 & -21 \\
\hline 86 & Geluids-, beeldapparatuurbedieners & 2.100 & 1.800 & -12 \\
\hline 71 & Mijn-, groeve-arbeider, boortechnici e.d. & 1.700 & 1.500 & -9 \\
\hline 52 & Leidinggevend huishoudelijk personeel & 10.400 & 9.600 & -8 \\
\hline 84 & Instrumentmakers, monteurs e.d. & 155.500 & 143.600 & -8 \\
\hline 38 & Telefonisten, telegrafisten & 18.100 & 17.000 & -6 \\
\hline 70 & Leidinggevend produktiepersoneel & 100.600 & 94.400 & -6 \\
\hline 94 & Ambachts- en industrieberoepen n.e.g. & 13.200 & 12.500 & -6 \\
\hline
\end{tabular}

Bron: ROA

Het datamateriaal beperkt zich hier tot slechts 4 AKT-jaren (1979-'85), vanwege de herziening van de onderwijsclassificatie van het CBS in 1978. Ook hier zijn de gegevens gepooled, waarbij voor iedere opleiding naast de tijdsdimensie ook de sector- en beroepsdimensie worden meegenomen.

Het opleidingenmodel wordt nader beschreven in Beekman, Dekker, De Grip en Heijke (1989). Op deze plaats zullen we de regressoren en de geschatte vergelijkingen slechts kort bespreken en uitgebreider stilstaan bij de uitkomsten van de schattingen van de werkgelegenheidsontwikkeling per opleidingstype voor de periode 19851992. Het opleidingenmodel bestaat uit twee stappen. Eerst wordt alleen een onderscheid gemaakt tussen opleidingsniveaus. Dit niveaumodel levert werkgelegenheidsprognoses uitgesplitst naar vijf niveaus, die corresponderen met het eerste cijfer van de SOI-code (basisonderwijs, mavo en lbo, havo/vwo en mbo, hbo, wetenschappelijk 
onderwijs). In de tweede stap wordt binnen elk niveau onderscheid gemaakt tussen de verschillende opleidingsrichtingen (b.v. technisch, agrarisch). Combinatie van opleidingsniveau en -richting leidt in totaal tot 53 opleidingstypen (zie bijlage 3 ).

Bij de modellering van het opleidingsniveau wordt de technologische ontwikkeling als mogelijke verklaring opgenomen voor de verschuivingen in de opleidingsniveaustructuur van beroepen in sectoren. Waar met nieuwe technologieën wordt gewerkt kan een upgrading van de functies plaats vinden, waardoor de invoering van de nieuwe technologie leidt tot hogere opleidingseisen. In bepaalde beroepen of bedrijfssectoren kan de mechanisering en automatisering echter ook tot verlaging van de functieniveaus leiden. $\mathrm{Er}$ is dan sprake van een downgrading proces. Het uiteindelijke effect is dus niet a priori vast te stellen. Als maatstaf voor de technologische ontwikkeling wordt, analoog aan het beroepenmodel in paragraaf 2.3, de kapitaalintensiteit en de mate van automatisering in een bedrijfssector genomen.

Verschuivingen in het opleidingsniveau van beroepen kunnen echter ook door aanbodfactoren worden geïnitieerd. Bij een ruime arbeidsmarkt kunnen lager geschoolde arbeidskrachten uit hun 'beroepsdomein' worden verdrongen door hoger gekwalificeerden. Men spreekt dan van neerwaartse verdringing, of 'bumping-down' processen. Deze vorm van verdringing werkt dus slechts één richting uit. Alleen personen met een hoger opleidingsniveau kunnen personen met een lager opleidingsniveau verdringen. Vanuit de neo-klassieke gedachtengang kan verdringing worden beschreven via de relatieve schaarste van een opleidingsniveau, die in de relatieve lonen tot uitdrukking komt. Aangezien echter geen adequate loongegevens voorhanden zijn moeten we volstaan met een benadering van deze relatieve schaarste. De verdringing kan in de neo-klassieke zienswijze zowel naar beneden als naar boven doorwerken. Als verklarende variabele is gekozen voor het aantal mensen met een bepaald opleidingsniveau als fractie van de totale potentiële beroepsbevolking (PBER).

Volgens vergelijking 2 wordt de omvang van het aandeel van opleidingsniveau $\mathrm{k}$ in een bepaald beroep $\mathrm{b}$ en sector $\mathrm{s}$ bepaald door een constante term, het aandeel van dit opleidingsniveau in de potentiële beroepsbevolking (de verdringingsvariabele), de investeringen per eenheid toegevoegde waarde in sector $\mathbf{s}$ en het aandeel van het automatiseringspersoneel in de werkgelegenheid van deze sector (de technologievariabelen). We gebruiken dummy variabelen voor de verschillende beroepen om rekening te houden met verschillen tussen beroepen die niet tot uiting komen in de genoemde exogenen. 
$\begin{aligned} \ln \left\{O_{\mathrm{kbst}}\right\}= & \lambda_{\mathrm{k}}+\nu_{\mathrm{k}} \cdot \ln \left\{\mathrm{PBER}_{\mathrm{kt}}\right\}+\omega_{\mathrm{k}} \cdot \ln \left\{\mathrm{INVTW}_{\mathrm{st}}\right\}+\mathrm{k}_{\mathrm{k}} \cdot \ln \left\{\mathrm{AUT}_{\mathrm{st}}\right\} \\ & +\eta_{\mathrm{bk}} \cdot \mathrm{g}_{\mathrm{b}}+\mu_{\mathrm{kbst}}\end{aligned}$

met $\mathrm{O}_{\mathrm{kbs}}: \quad \mathrm{E}_{\mathrm{kbs}} / \mathrm{E}_{\mathrm{bs}}=$ het aandeel werkzame personen $(\mathrm{E})$ met opleidingsniveau $k$ in het totaal aantal werkzame personen in beroepsklasse $\mathrm{b}$ in bedrijfssector $\mathbf{s}$

$\mathrm{PBER}_{\mathrm{k}}$ : het relatieve aandeel van opleidingsniveau $\mathrm{k}$ in de potentiële beroepsbevolking

INVTW $_{\text {St }}$ : de investeringen over de afgelopen 5 jaren in bedrijfssector $\mathbf{s}$ gedeeld door de toegevoegde waarde over de afgelopen 5 jaren in bedrijfssector $s$ in dat $j$ aar

$\mathrm{AUT}_{\text {St }}$ : het aandeel automatiseerders in de werkgelegenheid in bedrijfssector $s$ in dat $j a a r$

g1..79: beroependumm, $g_{b}=1$ als de waarneming betrekking heeft op beroepsklasse $b$

$\lambda, \nu, \omega, k, \eta: \quad$ parameters

$u_{k b s t}$ : storingsterm (normaal verdeeld)

$k, b, s, t$ : respectievelijk de opleidingsniveau-, beroepsklasse-, bedrijfssector- en tijdindex.

Voor het bepalen van het aandeel van een opleidingsrichting binnen een opleidingsniveau gebruiken we een eenvoudige specifikatie, waarin elk aandeel van een opleidingsrichting in een bepaald beroep in een bepaalde bedrijfssector wordt bepaald door een constante term en een trendterm. Er zijn geen verklarende variabelen opgenomen, omdat niet geheel duidelijk is welke processen een rol spelen bij de verklaring van het aandeel van de verschillende opleidingsrichtingen in de werkgelegenheid van een bepaald opleidingsniveau binnen een beroep. In principe zou het mogelijk zijn soortgelijke processen te veronderstellen als in de eerste stap zijn gemodelleerd en de daarbij behorende exogenen te specificeren, bijvoorbeeld analoog aan de PBER-variabele bij het niveaumodel - het aandeel van de verschillende richtingen in de potentiële beroepsbevolking. Dit blijkt echter niet mogelijk te zijn, omdat hiervoor de benodigde gegevens per opleidingsrichting ontbreken. De constante term is opgesplitst in een algemene constante, een beroepsspecifieke en een bedrijfssectorspecifieke constante. De specificatie luidt als volgt:

$\ln \left\{R_{1 b s k t}\right\}=\theta_{1}+\pi_{1 b} \cdot g_{b}+\xi_{1 s .} d_{s}+\tau_{1 b} \cdot T_{t}+\psi_{1 b s k t}$

met $R_{1 b s k t}: \quad E_{1 b s k t} / E_{b s k t}=$ Aandeel werkzame personen met opleidingsrichting 1 in beroepsklasse $b$, bedrijfssector $s$ en opleidingsniveau $k$ op tijdstip $t$

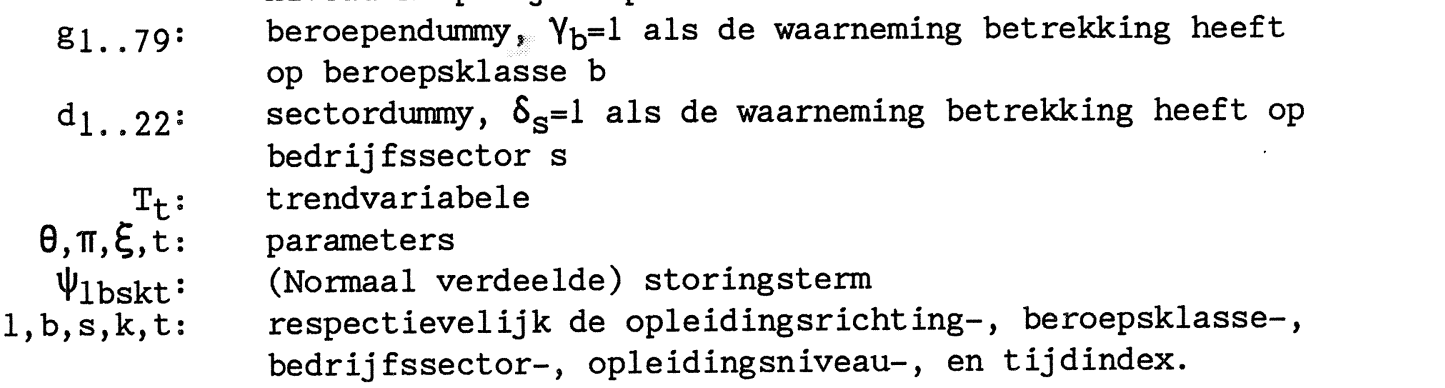


Analoog aan de eerste stap schatten we deze vergelijking per opleidingsrichting. Net als bij het beroepenmodel wordt hier ook een gewogen lineaire regressie uitgevoerd (zie paragraaf 2.3 ).

De modellering in twee stappen impliceert dat de ontwikkeling van het werkgelegenheidsaandeel van elk opleidingstype wordt opgesplitst in een onafhankelijk niveau- en richtingsaspect. In de eerste stap wordt het werkgelegenheidsaandeel naar opleidingsniveau vastgesteld. Een bepaald niveau impliceert overigens soms echter al bepaalde richtingen, omdat er op de diverse opleidingsniveaus uiteenlopende opleidingsrichtingen worden aangetroffen. De verschuivingen in de opleidingsstructuur qua richting die we in de tweede stap verklaren is derhalve additioneel aan de veranderingen in de richtingenstructuur die het opleidingsniveaumodel reeds impliceert.

In tabel 3 staan de grootste stijgers en dalers vermeld, die uit de doorberekening van het model voor 1992 naar voren komen. Met name bij de groeiers zien we zeer hoge percentages. Daarbij geldt dat bij de sterkste groeiers nogal eens sprake is van relatief kleine opleidingen. Het lager administratief onderwijs kent daarentegen een sterke daling van de werkgelegenheid, terwijl de vergelijkbare opleidingen op middelbaar niveau sterk toenemen.

Bij de cijfers van tabel 3 speelt de verschuiving van de beroepenstructuur in de richting van de dienstenberoepen een belangrijke rol (tabel 2). In tabel 3 staan immers de verschuivingen in de opleidingenstructuur nadat rekening is gehouden met de verschuivingen in de sector- en beroepenstructuur.

Tabel 3a. Werkzame personen naar opleidingstype 1985-1992; sterkste groeiers

\begin{tabular}{llccc}
\hline code & opleidingstype & $\begin{array}{c}\text { aantal } \\
\text { werkenden } \\
1985\end{array}$ & $\begin{array}{c}\text { aantal } \\
\text { werkenden } \\
1992\end{array}$ & $\begin{array}{c}\% \\
\text { groei }\end{array}$ \\
\hline & & & & \\
662 & Bedrijfskunde (ir.), econometrie en actuariaat & 3.600 & 11.100 & 212 \\
351 & Lager medisch en paramedisch onderwijs & 2.900 & 8.400 & 191 \\
652 & Farmacie, medische biologie e.d. & 1.700 & 4.300 & 159 \\
562 & Arbeidsanalist, bedrijfskunde (HTS) e.d. & 2.900 & 6.200 & 118 \\
554 & Opleiding diëtetiek e.d. & 1.900 & 3.200 & 66 \\
583 & Hogere hotelschool & 3.100 & 5.100 & 62 \\
431 & Middelbaar laboratoriumonderwijs (technisch) & 6.400 & 9.800 & 53 \\
452 & Middelbaar laboratoriumonderwijs (medisch) & 20.600 & 31.000 & 50 \\
483 & Middelbare horecaschool, kappersbedrijf & 32.500 & 48.200 & 48 \\
461 & Middelbare detailhandelschool en MEAO & 529.800 & 773.800 & 46
\end{tabular}


Tabel 3b. Werkzame personen naar opleidingstype 1985-1992; sterkste dalers

\begin{tabular}{|c|c|c|c|c|}
\hline code & opleidingstype & $\begin{array}{c}\text { aantal } \\
\text { werkenden } \\
1985 \\
\end{array}$ & $\begin{array}{c}\text { aantal } \\
\text { werkenden } \\
1992 \\
\end{array}$ & $\begin{array}{c}\% \\
\text { afname }\end{array}$ \\
\hline 341 & Lager transport-, communicatie- en verkeersonderwijs & 32.500 & 23.600 & -27 \\
\hline 586 & Kunstacademie, toneelschool, conservatorium & 27.400 & 21.500 & -21 \\
\hline 486 & Modetekenen e.d. & 1.900 & 1.500 & -21 \\
\hline 361 & LEAO, LMO, Kantoor/verkooppraktijk LHNO & 142.100 & 111.400 & -17 \\
\hline 506 & PABO, nieuwe lerarenopleiding (NLO) e.d. & 227.500 & 202.100 & -11 \\
\hline 406 & Opleidingen rij-instructeur, sportleider e.d. & 35.000 & 32.100 & -8 \\
\hline 671 & Sociale wetenschappen & 39.200 & 36.600 & -7 \\
\hline 511 & Tolk- en vertalersopleidingen & 4.800 & 4.500 & -6 \\
\hline 571 & Sociale academie, bibliotheekacademie e.d. & 67.100 & 64.500 & -4 \\
\hline 616 & Theologie & 7.900 & 7.500 & -4 \\
\hline
\end{tabular}

Bron: ROA 


\section{PROGNOSE VERVANGINGSVRAAG}

\subsection{Inleiding}

Naast de uitbreiding van het aantal arbeidsplaatsen, is ook de vervanging van toekomstige uitstromers die momenteel nog een functie vervullen van belang voor het aantal banen voor nieuwkomers op de arbeidsmarkt. De vervangingsvraag is het gevolg van enerzijds de definitieve uittrede uit de beroepsbevolking wegens pensionering, VUT, e.d. en anderzijds de doorgaans tijdelijke uittrede van met name gehuwde vrouwen, die zich voor een aantal jaren van de arbeidsmarkt terug trekken in verband met de opvoeding en verzorging van hun kinderen.

Ten behoeve van de werkgelegenheidsprognoses is een schatting gemaakt van de vervangingsvraag per beroepsklasse (paragraaf 3.2.). Hierbij speelt naast de uitstroom uit de beroepsbevolking ook het saldo van de uit- en instroom naar en vanuit de andere beroepsklassen een rol (de beroepsmobiliteit van de werkenden). Het gaat bij de uitgevoerde berekeningen om de theoretische vervangingsbehoefte. Of er daadwerkelijk nieuw personeel zal worden aangetrokken hangt af van de vraag of er geen sprake is van een dalende werkgelegenheid, dat wil zeggen een negatieve uitbreidingsvraag. Daarom wordt nagegaan in hoeverre de berekende vervangingsvraag in combinatie met de uitbreidingsvraag van een beroepsklasse inderdaad banen creëert voor nieuwkomers op de arbeidsmarkt. Tenslotte wordt in paragraaf 3.3 . de vervangingsvraag per beroepsklasse versleuteld naar de vervangingsbehoefte voor de verschillende opleidingstypen.

\subsection{Vervangingsvraag naar beroepsklasse}

Voor het bepalen van de vervangingsvraag per beroepsklasse, kan er in principe een verklarend model worden ontwikkeld. Nemen we echter de data-beperkingen in beschouwing en het feit dat er voor de exogenen van het model een voorspelling voor het jaar 1992 beschikbaar moet zijn, dan zou dit wel eens een moeizame weg kunnen worden. Vandaar dat we hier niet voor een regressiemodel hebben gekozen, maar voor een benadering via de leeftijdsopbouw van de beroepsbeoefenaren (de leeftijdscohorten per beroepsklasse).

Gegeven de beschikbare data over de werkgelegenheid per beroepsklasse naar leeftijdsklasse en geslacht voor 1979 en 1985 en de beroepsbevolking naar leeftijdsklasse en geslacht voor 1979, 1985 en 1992 (CPB, Op de Beke, 1987), kan aan de 
hand van de 'cohort'-methode een prognose van de vervangingsvraag per beroepsklasse worden gemaakt. Daarbij dient opgemerkt te worden dat vanwege de aard van de gegevens de vervangingsvraag niet bepaald kan worden voor zover deze door nieuwkomers in dezelfde leeftijdsklasse wordt opgevuld. Het meetbare verloop betreft derhalve de netto uitstroom van een cohort in de beroepsklasse.

We bepalen de vervangingsvraag aan de hand van het berekend verloop. Wanneer verondersteld wordt dat er binnen de onderscheiden leeftijdscohorten sprake is van een gelijkmatige spreiding van de beroepsbevolking over de jaargroepen binnen het cohort, kan voor ieder leeftijdsjaar worden bepaald hoeveel arbeidskrachten per saldo de beroepsbevolking verlaten of binnentreden. Daartoe vergelijken we het aantal arbeidskrachten met leeftijd c in 1985 met het aantal arbeidskrachten dat volgens de prognose in 1992 c+7 jaar oud is. Op basis hiervan kan de jaarlijkse netto uitstroom uit de beroepsbevolking voor de verschillende leeftijdscohorten worden berekend. Hieronder zal meer concreet worden aangegeven welke werkwijze hierbij is gevolgd.

Laat $\mathrm{BK}_{\mathrm{Ct}}$ het aantal werkzame personen in een beroepsklasse van cohort $\mathrm{c}$ op tijdstip $t$ zijn, dan is het verloop in de beroepsklasse tussen jaar $t$ en $t-j$ van cohort c:

$\mathrm{VBK}_{c t, t-j}=B K_{c, t} / \mathrm{BK}_{c, t-j}$

$\mathrm{BK}_{\mathrm{c}, t-\mathrm{j}}$ betreft hetzelfde cohort op het tijdstip $t-j$.

Analoog kan het verloop van het totaal aantal werkzame personen $\operatorname{VWP}_{c t, t-j}$ en van de totale beroepsbevolking $\mathrm{VBB}_{c t, t-j}$ worden bepaald. Al deze verloopratio's worden voor mannen en vrouwen apart bepaald. Per geslacht hebben we dan de volgende gegevens:

$\mathrm{VBK}_{\mathrm{c} 8579}, \mathrm{VWP}_{\mathrm{c} 8579}, \mathrm{VBB}_{\mathrm{c} 8579}$ en $\mathrm{VBB}_{\mathrm{c} 9285}$

Vanwege het feit dat de perioden 1979-'85 en 1985-'92 een verschillende lengte hebben rekenen we het verloop over een periode om naar jaarlijkse groeivoeten: $\mathrm{gVBK}_{\mathrm{c} 8579}, \mathrm{gVWP}_{\mathrm{c} 8579}, \mathrm{gVBB}_{\mathrm{c} 8579}$ en $\mathrm{gVBB}_{\mathrm{c} 9285}$.

Voor de bepaling van de vervangingsvraag is informatie nodig over het jaarlijkse verloop van de beroepsklassecohorten over de periode 1985-'92 voor alle c: $\mathrm{VBK}_{\mathrm{c} 8592}$. Dit verwachte verloop kan als volgt worden berekend:

$\mathrm{gVBK}_{\mathrm{c} 9285}=\mathrm{gVBK}_{\mathrm{c} 8579}-\left(\mathrm{gVWP}_{\mathrm{c} 8579}-\mathrm{gVBB}_{\mathrm{c} 9285}\right)$ 
Het jaarlijkse verloop per beroepsklasse is dus gelijk aan het verloop uit de beroepsklasse in de vorige periode, waarbij er in feite twee 'correcties' worden gemaakt. De eerste correctie betreft de conjuncturele component in de afgelopen periode: $\mathrm{gVBB}_{\mathrm{C} 8579}-\mathrm{gVWP}_{\mathrm{c} 8579}$. Door te corrigeren voor het verschil tussen het verloop uit de beroepsbevolking en het verloop uit de werkzame bevolking, wordt voorkomen dat een conjunctuurcomponent in het verloop (de uitstroom van werkenden naar het werklozenbestand) het beeld verstoort. De tweede correctiefactor, $\mathrm{gVBBC}_{9285}$ - $\mathrm{gVBB}_{\mathrm{C}} 8579$, geeft de verandering van het verloop van de totale beroepsbevolking in de toekomstige periode weer. Daarbij wordt verondersteld dat de verschillen in het algehele patroon van de uitstroom uit de beroepsbevolking tussen de periode 1985-'92 en 1979-'85 zich weerspiegelen in de verschillende beroepsklassen.

Daar het hier gaat om het berekenen van de vervangingsvraag en derhalve alleen om de uitstroom per beroepsklasse, kijken we alleen naar de cohorten waar de netto uitstroom positief is (met name de oudere leeftijdsgroepen). Sommatie van de uitstroom over de cohorten en de beide geslachten levert de berekende totale vervangingsvraag op voor de desbetreffende beroepsklasse.

Tabel $4 \mathrm{a}$ en $4 \mathrm{~b}$ vermelden de tien beroepsklassen met verhoudingsgewijs de hoogste en de laagste vervangingsvraag. De gemiddelde vervangingsvraag in de periode 1985-'92 bedraagd circa $18 \%$ van het aantal werkenden in 1985 . Voor verschillende met name industriële beroepsklassen is de gevonden vervangingsvraag duidelijk hoger dan gemiddeld. Daarbij moet wel bedacht worden dat hier zoals gezegd de theoretische vervangingsbehoefte wordt bepaald. In tabel $4 \mathrm{a}$ (beroepsklassen met een hoge vervangingsvraag) gaat het in veel gevallen om beroepsklassen waarin de werkgelegenheidsontwikkeling stagneert, waardoor de feitelijke vervanging slechts plaatsvindt voor zover de werkgelegenheid in de desbetreffende beroepsklasse niet inkrimpt.

Bij de beroepsklassen met een relatief lage vervangingsbehoefte treffen we diverse beroepen aan met een relatief jonge populatie, waaronder verschillende beroepen met veel academisch geschoolde arbeidskrachten. In deze beroepsklassen moeten de 'job openings' op de arbeidsmarkt in de nabije toekomst derhalve voor een belangrijk deel uit de groei van de werkgelegenheid komen. 
Tabel 4a. Beroepsklassen met relatief de hoogste vervangingsvraag 1985-1992

\begin{tabular}{llccc}
\hline code & beroepsklasse & $\begin{array}{c}\text { aantal werkenden } \\
1985\end{array}$ & $\begin{array}{c}\text { vervangings- } \\
\text { behoefte }\end{array}$ & $\begin{array}{c}\text { in } \% \text { van werkende } \\
\text { personen } \\
1985\end{array}$ \\
\hline & & & \\
75 & Spinners, wevers, ververs e.d. & 11.400 & 5.200 & 46 \\
99 & Sjouwers, dokwerkers e.d. & 45.900 & 18.300 & 40 \\
81 & Meubelmakers en andere houtbewerkers & 16.600 & 6.100 & 37 \\
71 & Mijn-, groeve-arbeiders, boortechnici e.d. & 1.700 & 600 & 35 \\
73 & Houtzagers, papiermakers & 7.200 & 2.500 & 35 \\
94 & Ambachts- en industrieberoepen n.e.g. & 13.200 & 4.600 & 35 \\
95 & Metselaar, timmerlieden, e.a. bouwvakarbeiders & 169.000 & 57.300 & 33 \\
83 & Smeden, gereedschapsmakers e.d. & 40.500 & 13.200 & 33 \\
87 & Loodgieters, pijpfitters, lassers e.d. & 104.500 & 34.500 & 32 \\
50 & Directeuren en bedrijfsleiders horecabedrijf & 13.200 & 4.200 & \\
\end{tabular}

Bron: ROA

Tabel 4b. Beroepsklassen met relatief de laagste vervangingsvraag 1985-1992

\begin{tabular}{llccc}
\hline code & beroepsklasse & $\begin{array}{c}\text { aantal werkenden } \\
1985\end{array}$ & $\begin{array}{c}\text { vervangings- } \\
\text { behoefte }\end{array}$ & $\begin{array}{c}\text { in \% van werkende } \\
\text { personen } \\
1985\end{array}$ \\
\hline & & & & \\
86 & Geluids-, beeldapparatuurbedieners & 2.100 & 0 & 0 \\
08 & Wiskundigen, systeemanalisten e.d. & 50.700 & 1.500 & 3 \\
15 & Journalisten, auteurs, redacteuren e.d. & 20.000 & 1.200 & 6 \\
78 & Tabakbewerkers, tabakpoduktenmakers & 2.100 & 100 & 8 \\
12 & Juristen, notarissen, rechters & 18.400 & 1.400 & 8 \\
40 & Directeuren en bedrijfsleiders groothandel & 30.200 & 2.200 & 9 \\
05 & Biologen, biochemici, landbouwkundigen e.d. & 29.300 & 2.600 & 9 \\
17 & Musici, dirigenten, toneelspelers e.d. & 17.600 & 1.500 & 9 \\
19 & Sociale hulpverleners, vertalers e.d. & 110.200 & 9.600 & 10 \\
41 & Directeuren en bedrijfsleiders detailhandel & 16.600 & 1.500 & \\
& & & & \\
\hline Bron: ROA & & & \\
\hline
\end{tabular}

Naast de vervangingsvraag per beroepsklasse is ook de vraag naar schoolverlaters op de arbeidsmarkt geprognosticeerd. Een deel van de totale vraag (uitbreidings- en vervangingsvraag) wordt namelijk opgevuld door intreders afkomstig uit andere beroepsklassen, de zogenaamde beroepsmobiliteit, en herintreders (in feite wel nieuwkomer, maar geen schoolverlater). Gegeven deze beroepsmobiliteit en herintreding kan de totale vraag naar schoolverlaters in een beroepsklasse als volgt worden gedefinieerd:

$\mathrm{C}$

$$
\mathrm{VS}_{\mathrm{b}}=\Delta \mathrm{E}_{\mathrm{b}}+\sum_{\mathrm{c}=1}\left(\mathrm{U}_{\mathrm{bc}}-\mathrm{H}_{\mathrm{bc}}\right) \text {, }
$$

met: $\mathrm{VS}_{\mathrm{b}}=$ vraag naar schoolverlaters in beroepsklasse $\mathrm{b}$;

$\Delta \mathrm{E}_{\mathrm{b}}=$ werkgelegenheidsverandering (uitbreidingsvraag);

$\mathrm{U}_{\mathrm{bc}}=$ uittrede $\mathrm{uit}$ beroepsklasse $\mathrm{b}$, cohort $\mathrm{c}$;

$\mathrm{H}_{\mathrm{bc}}=$ herintrede in beroepsklasse $\mathrm{b}$, cohort $\mathrm{c}$;

$\mathrm{C}=$ het aantal leeftijdscohorten. 
Werden bij de bepaling van de vervangingsvraag per beroepsklasse alleen die cohorten meegenomen waarvoor de netto uitstroom positief was $\left(U_{b c}-H_{b c}>0\right)$, bij de bepaling van de vraag naar schoolverlaters worden ook de cohorten meegenomen waarvoor de netto uitstroom negatief is als gevolg van de instroom vanuit andere beroepsklassen of de instroom van herintreders in de beroepsbevolking. Daarbij wordt verondersteld dat in de leeftijdsgroep onder de 30 jaar alleen schoolverlaters in een beroep stromen. In de praktijk zal dit natuurlijk lang niet altijd het geval zijn. Vandaar dat, wanneer hier van 'schoolverlaters' wordt gesproken, het in feite gaat om de instroommogelijkheden van arbeidskrachten jonger dan 30 jaar in een beroepsklasse.

Tabel 5a en 5b vermelden de beroepsklassen waarvoor tussen 1985 en 1992 in absolute en in relatieve zin de grootste vraag naar schoolverlaters wordt verwacht. Absoluut gezien zullen er veel 'schoolverlaters' kunnen instromen als administratief personeel, winkelpersoneel, bouwvakker, secretaresse, bankemployé of (genees- of) verpleegkundige. Relatief gezien is de vraag naar nieuwe jonge arbeidskrachten het hoogst in de beroepsklasse directeuren en bedrijfsleiders horecabedrijven, hetgeen enigszins verrassend is daar tal van andere leidinggevende beroepen niet direct bereikbaar zijn voor jonge arbeidskrachten (zie tabel 6.). Daarna volgen diverse industriële beroepen. Ook de vraag naar uitvoerende hoofdambtenaren is opvallend hoog.

In tabel 6 staan de beroepsklassen waarvoor in de periode 1985-'92 geen directe instroom van schoolverlaters wordt verwacht. Afgezien van een aantal ambachtelijke en industrieberoepen betreft het voornamelijk toezichthoudende en leidinggevende beroepen. Dit kan men verklaren uit het feit dat deze beroepen in principe geen startfuncties zijn, maar slechts bereikt kunnen worden na doorstroming vanuit andere be roepen.

Tabel 5a. Beroepsklassen met relatief hoge vraag naar schoolverlaters 1985-1992

\begin{tabular}{llc}
\hline code & beroepsklasse & in \% werkenden in 1985 \\
\hline 50 & Directeuren en bedrijfsleiders horecabedrijf & 55 \\
08 & Wiskundigen, systeemanalisten e.d. & 54 \\
75 & Spinners, wevers, verver e.d. & 44 \\
48 & Winkelbedienden, marktverkopers e.d. & 43 \\
32 & Secretaresses, (data)typistes e.d. & 41 \\
87 & Loodgieters, pijpfitters, lassers e.d. & 40 \\
34 & Computerapparatuur-operateurs e.d. & 38 \\
85 & Elektromonteurs, -reparateurs & 38 \\
63 & Boswachters en bosarbeiders & 37 \\
95 & Metselaars, timmerlieden e.a. bouwvakarbeiders & 36 \\
\hline
\end{tabular}


Tabel 5b. Beroepsklassen met absoluut hoge vraag naar schoolverlaters 1985-1992

\begin{tabular}{llc}
\hline code & beroepsklasse & aantal \\
\hline & & \\
39 & Diverse administratieve functies & 122.000 \\
48 & Winkelbedienden, marktverkopers e.d. & 107.900 \\
95 & Metselaars, timmerlieden e.a. bouwvakarbeiders & 60.800 \\
32 & Secretaresses, (data)typistes e.d. & 60.700 \\
33 & Bankemployees, lokettisten e.d. & 59.000 \\
06 & Medisch- en paramedisch personeel & 58.900 \\
98 & Chauffeurs, matrozen, treinbestuurders e.d. & 43.000 \\
87 & Loodgieters, pijpfitters, lassers e.d. & 42.200 \\
85 & Elektromonteurs, -reparateurs & 41.800 \\
02 & Ingenieurs, tekenaars e.d. & 41.200 \\
\hline
\end{tabular}

Bron: ROA

Tabel 6. Beroepsklassen waarvoor in de periode 1985-1992 geen directe instroom van schoolverlaters wordt verwacht

\begin{tabular}{ll}
\hline code & beroepsklasse \\
\hline 05 & Biologen, biochemici, landbouwkundigen e.d. \\
09 & Economen \\
12 & Juristen, notarissen, rechters \\
14 & Theologen, dominees, pastors e.d. \\
15 & Journalisten, auteurs, redacteuren e.d. \\
17 & Musici, dirigenten, toneelspelers e.d. \\
19 & Sociale hulpverleners, vertalers e.d. \\
20 & Hogere leidinggevende functies bij openbaar bestuur \\
21 & Beleidvoerende en hogere leidinggevende functies \\
30 & Leidinggevend administratief personeel \\
35 & Leidinggevend personeel transportbedrijf \\
37 & Postsorteerders, postbestellers e.d. \\
38 & Telefonisten, telegrafisten \\
40 & Directeuren en bedrijfsleiders groothandel \\
41 & Directeuren en bedrijfsleiders detailhandel \\
47 & Verzekeringsagenten, makelaars e.d. \\
52 & Leidinggevend huishoudelijk personeel \\
60 & Bedrijfsleiders land- en tuinbouw \\
70 & Leidinggevend produktiepersoneel \\
78 & Tabakbewerker, tabakproduktenmakers \\
80 & Schoenmakers, ledermakers \\
86 & Geluids-, beeldapparatuurbedieners \\
90 & Rubber-, plasticproduktenmaker \\
91 & Papierwaren-, kartonnagewerkers \\
96 & Machinisten e.a. bedieners van machines \\
& \\
\hline
\end{tabular}




\subsection{Vervangingsvraag naar opleidingstype}

Ook voor de vervangingsvraag naar opleiding zou het wenselijk zijn om een soortgelijk model of algoritme te ontwikkelen als ten aanzien van de beroepsklassen is gedaan. Hier speelt naast de dataproblemen echter ook een afstemmingsprobleem met betrekking tot de berekening van de uitbreidingsvraag. De vervangingsvraag voor opleidingstypen is een moeilijk te hanteren begrip. De beroepsmobiliteit geeft immers niet direct informatie over de vervangingsvraag naar opleiding en in de uitbreidingsvraag naar opleiding zit al een deel van de vervanging opgenomen. De uitbreidingsvraag naar opleidingstype omvat namelijk ook de verschuivingen tussen de verschillende opleidingstypen omvat binnen een beroepsklasse en daarmee impliciet ook de vervanging van een werknemer met een bepaalde opleidingsachtergrond door een nieuwkomer met een andere opleidingsachtergrond. Wat er voor de vervangingsvraag per opleiding over blijft om te verklaren is de vervangingsvraag in een beroepsklasse voor zover deze door nieuwkomers met dezelfde opleiding als de uitstromende mensen kan worden vervuld.

In een eerder stadium is getracht de vervangingsvraag te bepalen door eenvoudigweg na te gaan hoeveel 55+-ers er in 1985 per beroep waren en te veronderstellen dat deze groep tussen 1985 en 1992 volledig uitstroomt (De Grip, Heijke, Dekker en Groot, 1987). Vervolgens werden de uitkomsten via de beroepen-opleidingenstructuur van 1985 omgerekend naar de vervangingsvraag per opleiding. Ondat er geen gegevens voorhanden waren over de opleiding naar leeftijdsgroep binnen een beroepsklasse, moest in deze aanpak bovendien worden verondersteld dat de verdeling van de opleidingen per beroepsklasse niet afhankelijk is van de leeftijdsstructuur in een beroep. Deze werkwijze houdt derhalve geen rekening met de uitstroom van werkenden op jongere leeftijd (met name vrouwen). On dit probleem te ondervangen is gebruik gemaakt van een andere methodiek.

Ditmaal is de vervangingsvraag, zoals die in de vorige paragraaf per beroepsklasse is bepaald, verdeeld over de opleidingen via de beroepen-opleidingenstructuur. Ons realiserend dat ook deze methode niet optimal is, wordt thans gezocht naar meer adequate data (opleiding naar leeftijd en geslacht, participatiegraad e.d.) om over meer mogelijkheden te beschikken bij het construeren van een model van de vervangingsvraag per opleiding. Kijken we naar tabel 7a en 7b, waarin een aantal uitkomsten volgens de huidige aanpak - verdelen van de vervangingsvraag naar beroep over de opleidingen - worden vermeld, dan zien we dat de extreem hoge en lage percentages die bij de beroepen voorkwamen gedempt worden. Dit is hoogstwaarschijnlijk een gevolg van de methode om de vervangingsvraag naar beroep te verdelen over 
de opleidingen. Als we met name naar de grotere opleidingen kijken dan zien we dat bij de grootste stijgers veel lagere en middelbare opleidingen voorkomen, terwijl bij de geringe stijgers het opleidingsniveau hoger ligt.

Tabel 7a. Opleidingstypen met relatief de hoogste vervangingsvraag 1985-1992

\begin{tabular}{llcc}
\hline code & opleidingstype & vervangingsbehoefte & in \% van werkenden \\
& & 1985 \\
\hline & & & 23 \\
441 & Middelbaar transport-, communicatie- en verkeersonderwijs & 9.500 & 23 \\
541 & Hoger transport-, communicatie- en verkeersonderwijs & 4.700 & 21 \\
483 & Middelbare horecaschool, kappersbedrijf & 6.700 & 20 \\
421 & Middelbaar agrarisch onderwijs & 18.800 & 20 \\
453 & Opleiding medisch secretaresse e.d. & 800 & 19 \\
321 & Lager agrarisch onderwijs & 20.100 & 19 \\
361 & LEAO, LMO, kantoor/verkooppraktijk LHNO & 27.100 & 19 \\
381 & LHNO, excl. kantoor/verkooppraktijk & 43.300 & 19 \\
583 & Hogere hotelschool & 600 & 18 \\
431 & Middelbaar laboratoriumonderwijs (technisch) & 1.200 & \\
\end{tabular}

Bron: ROA

Tabel 7b. Opleidingstypen met relatief de laagste vervangingsvraag 1985-1992

\begin{tabular}{|c|c|c|c|}
\hline code & opleidingstype & vervangingsbehoefte & $\begin{array}{c}\text { in \% van werkenden } \\
1985\end{array}$ \\
\hline 652 & Farmacie, medische biologie e.d. & 200 & 10 \\
\hline 551 & HBO-verpleegkunde, fysiotherapie, logopedie & 5.000 & 11 \\
\hline 552 & Hoger laboratoriumonderwijs (medisch) & 2.000 & 11 \\
\hline 562 & Arbeidsanalist, bedrijfskunde (HTS) e.d. & 300 & 11 \\
\hline 571 & Sociale academie, bibliotheekacademie e.d. & 7.500 & 11 \\
\hline 606 & Universitaire lerarenopleiding, MO-B & 1.600 & 11 \\
\hline 611 & Letteren (universitair) & 1.900 & 11 \\
\hline 636 & Technische wetenscahppen & 4.200 & 11 \\
\hline 651 & Medische Wetenschappen & 3.800 & 11 \\
\hline 671 & Sociale Wetenschappen & 4.300 & 11 \\
\hline
\end{tabular}




\section{PROGNOSE POTENTIELE INSTROOM VAN SCHOOLVERLATERS}

\subsection{Inleiding}

Voor het aangeven van de mogelijkheden van schoolverlaters op de arbeidsmarkt kan niet worden volstaan met het presenteren van werkgelegenheidsprognoses. De kansen van schoolverlaters op de arbeidsmarkt worden immers mede bepaald door hun onderlinge competitie om de beperkt beschikbare banen. Een reëler inzicht in hun mogelijkheden op de arbeidsmarkt wordt daarom gegeven door de geprognosticeerde behoefte aan nieuwkomers op de arbeidsmarkt (de 'job openings') te confronteren met prognoses van de potentiële instroom uit het onderwijs. In hoofdstuk 5 wordt nader ingegaan op deze confrontatie van job openings en potentiële instroom. In dit hoofdstuk wordt ingegaan op de totstandkoming van de prognose van de potentiële instroom van schoolverlaters op de arbeidsmarkt. In vergelijking met de vorige rapportage over de mogelijkheden van onderwijsverlaters op de arbeidsmarkt (De Grip, Heijke, Dekker en Groot, 1987) is de prognose van de potentiële instroom van schoolverlaters op de arbeidsmarkt uitgebreid tot alle opleidingstypen.

\subsection{Methode}

Geprobeerd is om per opleidingstype een prognose voor de periode '85/'86 tot en met '91/'92 te maken van het aantal gediplomeerden dat uitstroomt naar de arbeidsmarkt. Een groot deel van de prognoseperiode is reeds verstreken. Voor zover het cijfermateriaal aanwezig was, hebben we daarom gebruik kunnen maken van gerealiseerde cijfers.

Voor het maken van de prognoses is geput uit de volgende bronnen:

- Tijdreeksen uit de onderwijsprognose 1988 van het CPB, ook wel aangeduid als SKILL '88.

- WORSA ' 88 en RHOBOS ' 88 van de Taakgroep Studentenramingen van het Ministerie van Onderwijs en Wetenschappen.

- Diverse CBS-statistieken (o.a. onderwijsmatrix 1985, statistieken van het erkend schriftelijk onderwijs).

- Andere externe informatie (leerlingengegevens door ons verkregen bij nietreguliere opleidingen).

De gevolgde methode wordt in figuur 1 schematisch weergegeven. 
Het Centraal Planbureau (CPB) publiceert jaarlijks een prognose van de leerlingenbezetting in het dagonderwijs, het aantal schoolverlaters en het opleidingsniveau van de bevolking tot het studiejaar 2000/2001. Dit zijn de zogenaamde 'SKILL-prognoses'. Deze prognoses zijn gedifferentieerd naar geslacht en leeftijd. Het aggregatieniveau van de SKILL- gegevens is veel hoger dan het aggregatieniveau van de door ons onderscheiden opleidingstypen. Het is derhalve noodzakelijk om tot verdeelsleutels te komen, waarmee de SKILL-prognoses verbijzonderd kunnen worden naar de opleidingen die door ons worden onderscheiden.

In WORSA (Wetenschappelijk Onderwijs Raming Studenten Aantallen) en RHOBOS (Raming Hoger BeroepsOnderwijs Studentenaantallen) worden voor respectievelijk het wetenschappelijk en het hoger beroepsonderwijs ramingen gegeven voor het aantal personen dat het onderwijs verlaat. Beide prognoses baseren hun gegevens overigens ook op de SKILL-prognose van het Centraal Planbureau. In feite worden de desbetreffende opleidingen uit SKILL verbijzonderd naar een lager aggregatieniveau. De verbijzonderingen die in WORSA en RHOBOS worden gemaakt sluiten echter niet direct aan bij de opleidingstypen die door ons worden onderscheiden. Vandaar dat een aantal opleidingen die in WORSA en RHOBOS worden onderscheiden moeten worden samengenomen, of juist verbijzonderd.

Voor het lager en middelbaar beroepsonderwijs en het algemeen voortgezet onderwijs zijn er geen equivalenten beschikbaar van studies zoals RHOBOS en WORSA. Daarom moet hier direct worden uitgegegaan van de SKILL-prognoses en moeten door ons zelf verdeelsleutels worden vastgesteld om te kunnen verbijzonderen naar de in het informatiesysteem onderscheiden opleidingstypen. Vervolgens moeten de gediplomeerdenramingen worden omgezet in uitstroompercentages uit het onderwijs. Dit is nodig omdat leerlingen kunnen doorstromen naar vervolgopleidingen in het dagonderwijs, in plaats van zich aan te bieden op de arbeidsmarkt.

Naast de gediplomeerde schoolverlaters onderscheidt SKILL ook schoolverlaters die het desbetreffende onderwijstype zonder diploma verlaten. Met behulp van de onderwijsmatrix wordt deze groep alsnog toegerekend aan de vooropleiding die zij wel met een diploma hebben afgesloten. 
Figuur 1. UITSTROOMRAMINGEN REGULIER EN NIET-REGULIER ONDERWIJS NAAR OPLEIDINGSTYPE

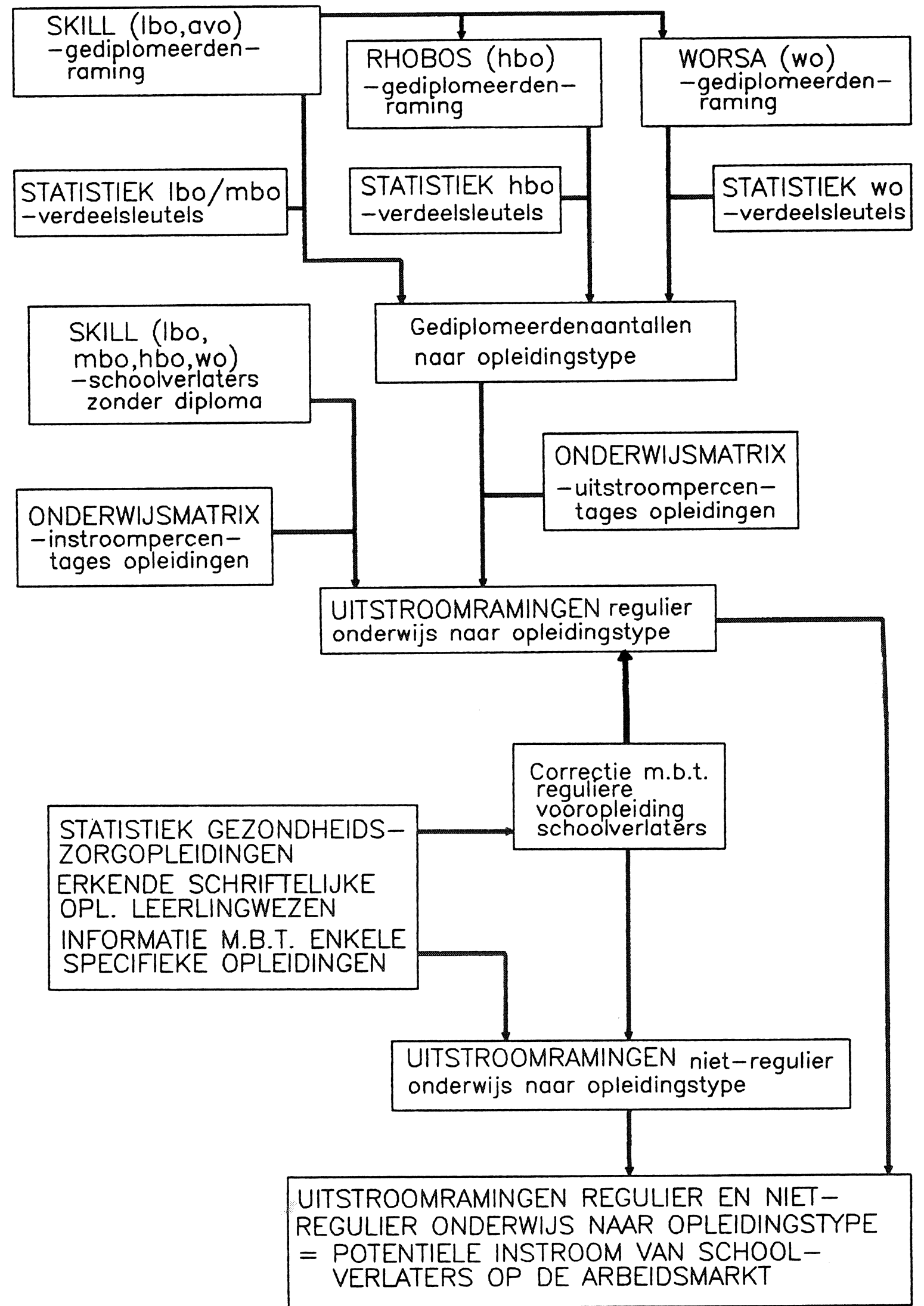


Voor het niet-reguliere onderwijs (leerlingwezen, erkende schriftelijke opleidingen, gezondheidszorgopleidingen e.d.) is men aangewezen op additionele statistieken van het CBS, het CORO en rechtstreekse contacten met bepaalde opleidingen. Ook voor deze categorie wordt een prognose van de instroom op de arbeidsmarkt gemaakt. Door het behalen van een opleiding in het niet-reguliere onderwijs verandert echter het kwalificatieprofiel van de 'schoolverlaters'. Vandaar dat de geslaagden als een minpost moeten worden versleuteld over de reguliere vooropleidingen waarmee men in het niet-reguliere onderwijs instroomde. Daarbij moet echter worden gecorrigeerd voor dubbeltellingen die ontstaan wanneer men meerdere niet-reguliere opleidingen, of een reguliere opleiding die onder hetzelfde opleidingstype valt, heeft gevolgd. Op deze wijze ontstaat een prognose van de uitstroom uit zowel het reguliere als het niet-reguliere onderwijs naar de arbeidsmarkt ${ }^{3}$.

\subsection{Resultaten}

In tabel 8 wordt de potentiële instroom van de onderscheiden opleidingstypen op de arbeidsmarkt weergegeven. De instroom is gecumuleerd over de periode 1985-1992 en uitgedrukt in procenten van het aantal werkzame personen in 1985 met de desbetreffende opleidingsachtergrond.

Een hoge instroom hoeft niet automatisch te leiden tot slechte vooruitzichten op de arbeidsmarkt. Een hoge instroom kan zelfs wenselijk zijn als de vraag naar bepaalde opgeleiden eveneens hoog is. Toch wordt de potentiële instroom apart weergegeven. Zouden we volstaan met het presenteren van alleen de uitkomsten van de confrontatie van de potentiële instroom en de job openings dan kunnen we niet traceren of bijvoorbeeld een slecht arbeidsmarktperspectief nu veroorzaakt wordt door een hoge instroom of een lage vraag naar arbeidskrachten met de desbetreffende opleiding, of door beide factoren.

Met name bij het hoger beroeps- en wetenschappelijk onderwijs zijn hoge instroompercentages waar te nemen. Op MBO-niveau zien we bij Modetekenen (486) eveneens een hoge potentiële instroom, maar hier zou men zich kunnen afvragen of deze personen zich allemaal daadwerkelijk op de arbeidsmarkt zullen aanbieden. Ook de opleidingen bedrijfsbeveiliging en -bewaking (391) kennen een zeer hoge instroom. Hierbij kan worden opgemerkt dat het gemiddeld aantal werkenden in de periode 1979-

3. Hierbij moet worden opgemerkt dat met name de aanwezige gegevens voor het nietreguliere onderwijs vooralsnog sumier zijn en dat er naar gestreefd wordt om op dit onderdeel tot een meer systematische gegevensverzameling te komen. 
'85 3.600 bedraagt en het derhalve een relatief kleine opleiding betreft. Een middelmatige absolute stijging werkt dan procentueel sterker door.

Tabel 8. Potentiële instroom per opleidingstype op de arbeidsmarkt, 1985-1992, in procenten van het aantal werkzame personen in 1985

\begin{tabular}{llr} 
code & opleidingstype & instroo \\
\hline & Lager beroepsonderwijs, MAVO & 23 \\
301 & MAVO en HAVO, VWO (onderbouw) & 36 \\
321 & Lager agrarisch onderwijs & 25 \\
331 & Lager technisch onderwijs & 29 \\
341 & Lager transport-, communicatie- en verkeersonderwijs & 16 \\
351 & Lager medisch en paramedisch onderwijs & 45 \\
361 & LEAO, LMO, kantoor/verkooppraktijk LHNO & 19 \\
381 & LHNO, excl. kantoor/verkooppraktijk & 224
\end{tabular}

Middelbaar beroepsonderwijs, HAVO-VWO

$\begin{array}{llr}401 & \text { HAVO en VWO (bovenbouw) } & 101 \\ 406 & \text { Opleidingen rij-instructeur, sportleider e.d. } & 14 \\ 421 & \text { Middelbaar agrarisch onderwijs } & 38 \\ 431 & \text { Middelbaar laboratoriumonderwijs (technisch) } & 80 \\ 436 & \text { Middelbaar technisch onderwijs } & 47 \\ 441 & \text { Middelbaar transport-, communicatie- en verkeersonderwijs } & 35 \\ 451 & \text { Verpleegkunde en doktersassistente MDGO } & 46 \\ 452 & \text { Middelbaar laboratoriumonderwijs (medisch) } & 44 \\ 453 & \text { Opleiding medisch secretaresse e.d. } & 118 \\ 454 & \text { Opleiding ziekenverzorging e.d. } & 61 \\ 461 & \text { Middelbare detailhandelschool en MEAO } & 39 \\ 466 & \text { MEAO-bestuurlijke richting } & 17 \\ 471 & \text { Sociale arbeid en agogisch werk (MDGO) } & 118 \\ 481 & \text { Uiterlijke verzorging, verzorging MDGO, INTAS } & 57 \\ 483 & \text { Middelbare horecaschool, kappersbedrijf } & 21 \\ 486 & \text { Modetekenen e.d. } & 170\end{array}$

Hoger beroepsonderwijs

$506 \quad$ PABO, nieuwe lerarenopleiding (NLO) e.d.

$511 \quad$ Tolk- en vertalersopleidingen

Opleiding pastoraal werk e.d.

Hoger agrarisch onderwijs

Hoger laboratorium onderwijs (technisch)

Hoger technisch onderwijs

$\begin{array}{lr}\text { Hoger transport-, communicatie- en verkeersonderwijs } & 18 \\ \text { HBO-verpleegkunde, fysiotherapie, logopedie } & 104\end{array}$

$\begin{array}{lr}\text { Hoger laboratoriumonderwijs (medisch) } & 104 \\ 28\end{array}$

$\begin{array}{lr}\text { Opleiding diëtetiek e.d. } & 102\end{array}$

HEAO, excl. bestuurlijke en fiscale richting

$\begin{array}{lr}\text { Arbeidsanalist, bedrijfskunde (HTS) e.d. } & 119\end{array}$

HEAO, juridische en bestuurlijke richting

Sociale academie, bibliotheekacademie e.d.

$\begin{array}{ll}\text { Hogere hotelschool } & 68\end{array}$

Kunstacademie, toneelschool, conservatorium $\quad 62$

Wetenschappelijk onderwijs

Universitaire lerarenopleiding, MO-B

$\begin{array}{lr}\text { Letteren (universitair) } & 121 \\ & \end{array}$

Theologie (universitair) 13

$\begin{array}{lr}\text { Agrarische wetenschappen } & 103\end{array}$

Wiskunde en natuurwetenschappen $\quad 56$

$\begin{array}{ll}\text { Technische wetenschappen } & 48\end{array}$

Medische wetenschappen $\quad 45$

$\begin{array}{lr}\text { Farmacie, medische biologie e.d. } & 125\end{array}$

Economie, bedrijfskunde (drs.), informatica

$\begin{array}{lr}\text { Bedrijfskunde (ir.), econometrie en actuariaat } & 105\end{array}$

Rechtsgeleerdheid en bestuurskunde $\quad 95$

Sociale wetenschappen $\quad 90$

Kunstwetenschappen $\quad 224$ 


\section{JOB OPENINGS EN ARBEIDSMARKTPERSPECTIEVEN}

\subsection{Inleiding}

Zoals in hoofdstuk 4 reeds is opgemerkt, wordt alleen voor opleidingen een confrontatie van de verwachte potentiële instroom op de arbeidsmarkt en de totale vraag in de prognoseperiode gemaakt. Een confrontatie van job openings en verwacht potentieel aanbod is niet te maken voor beroepen. De reden hiervoor is dat opleiding een persoonlijk kenmerk is, waaruit niet eenduidig het aanbod voor een beroep valt af te leiden. Pas op het niveau van de opleidingskwalificaties worden vraag en aanbod op de arbeidsmarkt met elkaar geconfronteerd. Op de arbeidsmarkt gaat het dus om gevraagde en aangeboden kwalificaties.

Men mag het verschil tussen job openings en verwacht potentieel aanbod niet interpreteren in termen van werkloosheid. In de eerste plaats wordt er zoals gezegd niet gekeken naar het verwachte feitelijke aanbod op de arbeidsmarkt, maar naar het potentiële aanbod. In de tweede plaats is er geen rekening gehouden met de werkloosheidsomvang in het basisjaar van de prognoseperiode. Dit is onder meer gedaan om te voorkomen dat de prognoses toch zouden worden vertaald in termen van de verwachte werkloosheid. Het is overigens ook moeilijk om vast te stellen in hoeverre er nog sprake is van daadwerkelijke concurrentie tussen schoolverlaters en met name langdurig werklozen. Bovendien is het heel goed mogelijk dat, hoewel er in het werkgelegenheidsmodel voor opleidingen terdege rekening is gehouden met verdringingseffecten, dergelijke effecten bij een erg ruime arbeidsmarkt nog veel groter zullen uitvallen dan door ons is aangenomen. Dit zou betekenen dat bij een relatief groot overschot van hoger geschoolden, de schoolverlaters in sterkere mate in banen (ver) onder het niveau van de genoten opleiding zouden instromen dan wij hebben geprognosticeerd. Vanuit het oogpunt van de studie- en beroepskeuze is het ons inziens terecht om in dat geval, ook al is men later niet werkloos, toch te spreken van een slecht arbeidsmarktperspectief.

In paragraaf 5.2 wordt een overzicht gegeven van de job openings per beroepsklasse en opleidingstype. In Paragraaf 5.3 wordt per opleidingstype een arbeidsmarktperspectief afgeleid op basis van de verhouding tussen de potentiële instroom op de arbeidsmarkt en de job openings per opleidingstype.

\subsection{Job openings}

Onder de term job openings verstaan we, zoals reeds opgemerkt, het totaal van de vervangings- en uitbreidingsvraag. Deze term wordt door het Bureau of Labor 
Statistics van het Amerikaanse Ministerie van Werkgelegenheid gebruikt om aan te geven dat banen kunnen ontstaan als gevolg van toenemende werkgelegenheid maar ook als gevolg van vervangingsvraag. Ondat het aantal nieuwe banen per definitie niet negatief kan zijn, is het aantal job openings per beroep groter of gelijk aan 0 . Vandaar dat in tabel 9, waarin de job openings worden onderscheiden in uitbreidingsen vervangingsvraag, de job openings op 0 zijn gezet in het beperkte aantal gevallen waarvoor optellen van uitbreidings- en vervangingsvraag leidt tot een negatieve totale vraag.

De cijfers van tabel 9 laten zien dat de vervangingsvraag een niet te verwaarlozen component van het totaal aantal verwachte job openings uitmaakt. Voor de leidinggevende beroepen ( $\mathrm{vg} 1$. codes $20,30,50,60$ en 70) geldt dat in een aantal gevallen de uitbreidingsvraag laag is en de vervangingsvraag daarentegen hoog. Dit betekent dat het aantal arbeidsplaatsen in de desbetreffende beroepen vrij stabiel is, maar dat er als gevolg van de relatief grote uitstroom van ouderen uit deze beroepen er toch beweging op de arbeidsmarkt is voor dit beroep. Bij de beroepen uit de beroepssectoren administratieve en commerciële functies (eerste cijfer van de code is gelijk aan 3 resp. 4) zal naar verwachting ook sprake zijn van relatief veel job openings.

\subsection{Arbeidsmarktperspectieven naar opleidingstype}

In tabel 10 worden de job openings voor de verschillende opleidingen weergegeven, waarbij analoog aan tabel 9 een uitsplitsing in uitbreidings- en vervangingsvraag is gemaakt. Tabel 10 laat ook weer het belangrijke aandeel van de vervangingsvraag in het totaal aantal job openings zien. De vervangingsvraag naar opleiding kent over het algemeen minder extrema dan bij de beroepen het geval was. Dit kan echter, zoals gezegd, komen door een demping van de vervangingsvraag bij de opleidingen door de weging met de beroepenstructuur van de opleidingen.

In tabel 11 wordt het quotiënt van de potentiële instroom op de arbeidsmarkt en de job openings weergegeven. Naarmate er meer instroom is ten opzichte van de vraag, wordt het quotiënt groter. Een hoog verhoudingscijfer geeft dus een ruime arbeidsmarkt voor de desbetreffende opleiding weer en een laag quotiënt wijst er op dat de desbetreffende deelmarkt naar verwachting in de nabije toekomst krap zal zijn. Voor een aantal opleidingstypen vinden we extreem hoge, of negatieve uitkomsten. Negatieve uitkomsten zijn het gevolg van een 'negatieve' vraag. Dit is mogelijk, omdat we bij de opleidingen de negatieve job openings niet op 0 hebben gesteld. 
Het quotiënt van potentiële instroom en job openings wordt vertaald in een 'kwalitatieve typering van het verwachte arbeidsmarktperspectief'. Een dergelijke kwalitatieve typering is ons inziens toereikend ten behoeve van de studie- en beroepskeuze en voorkomt bovendien dat er ten onrechte te veel waarde wordt gehecht aan de exacte prognoseresultaten. In de classificatie van de te verwachten arbeidsmarktperspectieven is uitgegaan van een vijfdeling:

quotiënt $\leq 0$, of quotiënt > 8

$4<$ quotiënt $\leq 8$

$2<$ quotiënt $\leq 4$

$1<$ quotiënt $\leq 2$

$0<$ quotiënt $\leq 1$

\author{
erg slecht arbeidsmarktperspectief \\ slecht arbeidsmarktperspectief \\ matig arbeidsmarktperspectief \\ redelijk arbeidsmarktperspectief \\ goed arbeidsmarktperspectief
}

Voor de opleidingen met een negatief quotiënt blijkt er sprake te zijn van een daling van de vraag, terwijl het aanbod niet extreem hoog is. Een uitzondering vormt opleidingstype 486, Modetekenen e.d. waarbij het aanbod wel erg groot is. Een erg slechte arbeidsmarktsituatie wordt eveneens verwacht voor 361, Leao, 1mo, kantoor/verkooppraktijk 1hno; 506, Pabo, nieuwe lerarenopleiding e.d.; 511, Tolk- en vertalersopleidingen; 571, Sociale academie, bibliotheekacademie e.d.; en 671, Sociale wetenschappen, waar de vraag weliswaar positief, doch zeer klein is.

Bij de opleidingen 391, Opleidingen bedrijfsbeveiliging en -bewaking; 401, Havo/vwo; 611 Letteren; en 686, Kunstwetenschappen, is er daarentegen sprake van een slechte arbeidsmarktsituatie door een relatief grote instroom. Een goed arbeidsmarktperspectief geldt voor de opleidingen 301, Mavo en Havo, Vwo (onderbouw); 331, Lager technisch onderwijs; 351, Lager medisch en paramedisch onderwijs; 381, Lhno, exc1. kantoor/verkooppraktijk; 421, Middelbaar agrarisch onderwijs; 441, Middelbaar transport-, communicatie- en verkeersonderwijs; 452, Middelbaar laboratorium onderwijs (medische richting); 461, Middelbare detailhandelschool (Mds) en Meao; 466, MEAO-bestuurlijke richting; 483, Middelbare horecaschool, kappersbedrijf e.d.; 516, Opleiding pastoraal werk e.d.; 541, Hoger transport-, communicatie- en verkeersonderwijs; 561,566, Heao; 562, Arbeidsanalist, bedrijfskunde (Hts) e.d.; 583, Hogere hotelschool; 652, Farmacie, medische biologie e.d. en 662, Bedrijfskunde (ir.), econometrie en actuariaat. 
Tabel 9. Uitbreidingsvraag, vervangingsvraag en job openings per beroepklasse, 1985-1992, in procenten van het aantal werkzame personen 1985

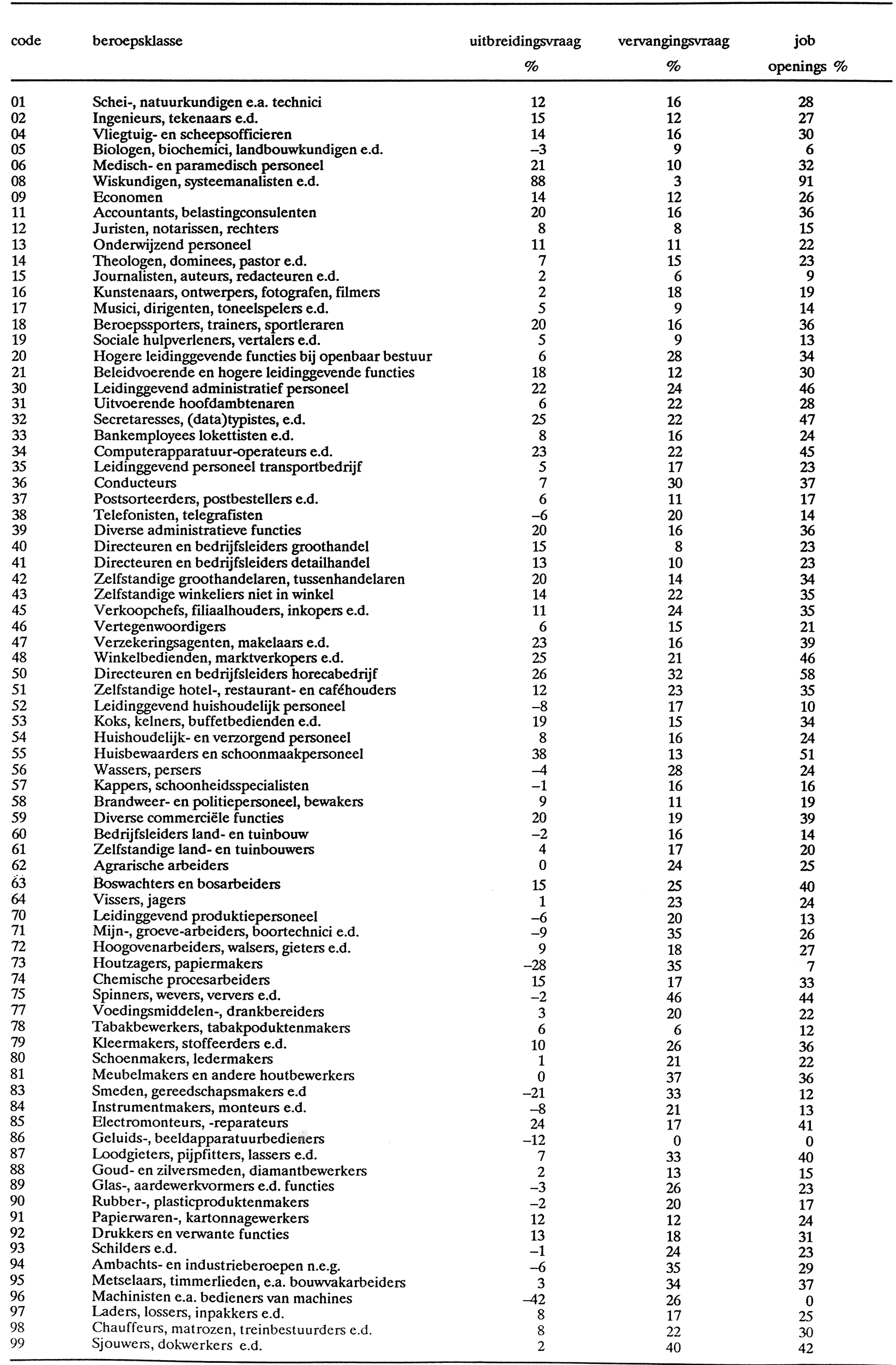


Tabel 10. Uitbreidingsvraag, vervangingsvraag en job openings per opleidingstype, $1985-1992$, in procenten van het aantal werkzame personen in 1985

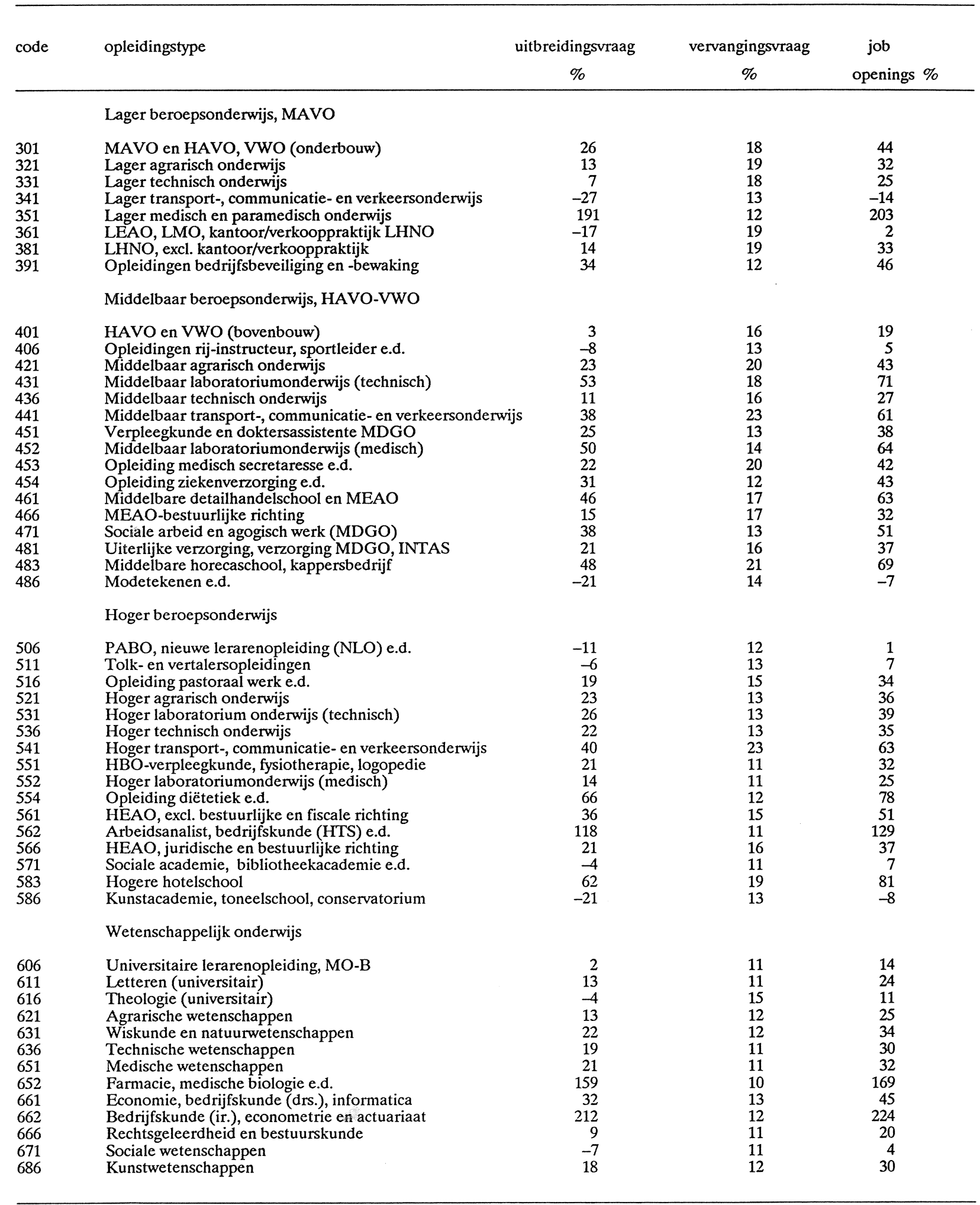


Tabel 11. Quotiënt aanbod/vraag per opleidingstype, 1985-1992

\begin{tabular}{llcc}
\hline code & opleidingstype & quotiënt & kwalificatie \\
& & arbeidsmarktperspectief \\
\hline
\end{tabular}

Lager beroepsonderwijs, MAVO

\author{
MAVO en HAVO, VWO (onderbouw) \\ Lager agrarisch onderwijs \\ Lager technisch onderwijs \\ Lager transport-, communicatie- en verkeersonderwijs \\ Lager medisch en paramedisch onderwijs \\ LEAO, LMO, kantoor/verkooppraktijk LHNO \\ LHNO, excl. kantoor/verkooppraktijk \\ Opleidingen bedrijfsbeveiliging en -bewaking
}

Middelbaar beroepsonderwijs, HAVO-VWO

HAVO en VWO (bovenbouw)

Opleidingen rij-instructeur, sportleider e.d.

Middelbaar agrarisch onderwijs

Middelbaar laboratoriumonderwijs (technisch)

Middelbaar technisch onderwijs

Middelbaar transport-, communicatie- en verkeersonderwijs

Verpleegkunde en doktersassistente MDGO

Middelbaar laboratoriumonderwijs (medisch)

Opleiding medisch secretaresse e.d.

Opleiding ziekenverzorging e.d.

Middelbare detailhandelschool en MEAO

MEAO-bestuurlijke richting

Sociale arbeid en agogisch werk (MDGO)

Uiterlijke verzorging, verzorging MDGO, INTAS

Middelbare horecaschool, kappersbedrijf

Modetekenen e.d.

0.52
1.13
1.00
-2.07
0.08
22.50
0.58
4.87

goed

redelijk

goed

erg slecht

goed

erg slecht

goed

slecht

Hoger beroepsonderwijs

PABO, nieuwe lerarenopleiding (NLO) e.d.

Tolk- en vertalersopleidingen

Opleiding pastoraal werk e.d.

Hoger agrarisch onderwijs

Hoger laboratorium onderwijs (technisch)

Hoger technisch onderwijs

Hoger transport-, communicatie- en verkeersonderwijs

HBO-verpleegkunde, fysiotherapie, logopedie

Hoger laboratoriumonderwijs (medisch)

Opleiding diëtetiek e.d.

HEAO, excl. bestuurlijke en fiscale richting

Arbeidsanalist, bedrijfskunde (HTS) e.d.

HEAO, juridische en bestuurlijke richting

Sociale academie, bibliotheekacademie e.d.

Hogere hotelschool

Kunstacademie, toneelschool, conservatorium

Wetenschappelijk onderwijs

Universitaire lerarenopleiding, MO-B

Letteren (universitair)

Theologie (universitair)

Agrarische wetenschappen

Wiskunde en natuurwetenschappen

Technische wetenschappen

Medische wetenschappen

Farmacie, medische biologie e.d.

Economie, bedrijfskunde (drs.), informatica

Bedrijfskunde (ir.), econometrie en actuariaat

goed

matig

goed

redelijk

goed

matig

redelijk

redelijk

goed

goed

goed

erg slecht

goed

erg slecht

Sociale wetenschappen

Kunstwetenschappen

slecht
slecht
redelijk
slecht
redelijk
redelijk
redelijk
goed
redelijk
goed
slecht
erg slecht
slecht

* In I-See! wordt hierbij de kanttekening gemaakt dat beschikbare specifieke arbeidsmarktprognoses voor het PABO wijzen op goede arbeidsmarktperspectieven voor afgestudeerden van deze opleiding. 


\section{RISICO-INDICATOREN}

\subsection{Inleiding}

Zoals in het eerste hoofdstuk is opgemerkt, worden naast prognoses ook arbeidsmarktindicatoren ontwikkeld op basis van historische gegevens. Deze aanvullende indicatoren beogen een verruiming te geven van het begrip toekomstmogelijkheden van opleidingen. In een eerder verschenen ROA-werkdocument van De Grip en Heijke (1988) is een inventarisatie gemaakt van verschillende typen arbeidsmarktindicatoren, hun doelgroep en de eisen met betrekking tot de data. In deze rapportage zullen we alleen stilstaan bij de indicatoren die boven de gegeven prognoses van vraag en aanbod aanvullende informatie geven over de onzekerheid ten aanzien van de toekomstige arbeidsmarktperspectieven die is verbonden aan de vervulling van bepaalde beroepen of aan de keuze voor een bepaalde opleiding. Deze zogenaamde risicoindicatoren zijn de conjunctuurgevoeligheid van de werkgelegenheid in beroepen, de uitwijkmogelijkheden naar andere bedrijfssectoren van een bepaald beroep en de uitwijkmogelijkheden naar andere beroepen en bedrijfssectoren voor een opleiding.

Deze indicatoren vormen een maatstaf voor de werkzekerheid en de flexibiliteit van het beroep of de opleiding op de arbeidsmarkt. Uit deze indicatoren kan bijvoorbeeld worden afgeleid of een opleiding opleidt tot maar één beroep, dat bovendien ook nog vrijwel alleen in een zeer conjunctuurgevoelige sector voorkomt, of dat er daarentegen met de opleiding veel uitwijkmogelijkheden zijn naar andere beroepen en sectoren waarvan de werkgelegenheid bovendien weinig conjunctuurgevoelig is. In paragraaf 6.2 wordt ingegaan op de conjunctuurgevoeligheid per beroep, terwij1 paragraaf 6.3 de uitwijkmogelijkheden per beroep en per opleiding behandelt.

\subsection{Conjunctuurgevoeligheid}

De prognoses van vraag en aanbod op de arbeidsmarkt betreffen middellange-termijnramingen die conjunctuur-neutraal zijn. On de conjunctuurgevoeligheid van afzonderlijke sectoren na te gaan, kan men onderzoeken hoe de reactie van de werkgelegenheid op conjunctuurschommelingen in het verleden is geweest. Hiertoe is, in navolging van het NEI (1972) een fluctuatie-index geconstrueerd. De formule luidt als volgt:

$$
\mathrm{FI}_{\mathbf{S}}=\frac{100}{\mathrm{H}} \stackrel{\mathrm{H}=1}{\sum} \frac{\left.\mathrm{F}_{\mathrm{St}}\right\rfloor}{\mathrm{T}_{\mathrm{St}}}
$$


waarin:

$F I_{\mathbf{S}}=$ Fluctuatie-index bedrijfssector $\mathbf{s}$

$\mathrm{H}=$ Aantal waarnemingsjaren

$F_{\text {St }}=$ Afwijking van trendmatige werkgelegenheidsontwikkeling van bedrijfssector $s$ op tijdstip $t$

$\mathrm{T}_{\mathrm{st}}=$ Trendmatige werkgelegenheidsontwikkeling van bedrijfssector $\mathbf{s}$ op tijdstip $t$.

De trendmatige ontwikkeling van de werkgelegenheid wordt bepaald door het 5jaarlijkse voortschrijdend gemiddelde te nemen van de werkgelegenheid $\mathrm{E}_{\mathrm{st}}$ :

2

$\mathrm{T}_{\mathrm{st}}=[1 / 5] \Sigma \mathrm{E}_{\mathrm{st}}+\mathrm{h}$ $h=-2$

De afwijking van de trend, Fst, wordt vervolgens berekend door het absolute verschil te nemen van de werkgelegenheid $\mathrm{E}_{\mathbf{S t}}$ en de trend $\mathrm{T}_{\mathbf{s t}}$.

De fluctuatie-indices van de sectoren worden berekend over de periode 1950-1988. De index voor elke beroepsklasse wordt bepaald door de indices van de sectoren te wegen met het aandeel van de desbetreffende beroepsklasse in de sectorale werkgelegenheid in 1985:

$$
F I_{b}=\sum_{s=1}^{S} a_{b s} F I_{s}
$$

waarin:

$\mathrm{FI}_{\mathrm{b}}=$ Fluctuatie-index voor beroepsklasse $\mathrm{b}$

$a_{b s}=$ Aandeel beroepsklasse $b$ in de werkgelegenheid van bedrijfssector $s$

Door deze berekeningswijze is impliciet aangenomen dat de werkgelegenheid van de verschillende beroepen binnen een bedrijfssector in gelijke mate fluctueert. In de praktijk behoeft dat echter niet het geval te zijn 4 . Er is evenwel geen lange tijdreeks beschikbaar van de werkgelegenheid per sector naar beroep, hetgeen nodig zou zijn om een meer verfijnde index te berekenen. Tabel $12 \mathrm{a}$ en $12 \mathrm{~b}$ vermelden de tien beroepsklassen met de grootste, respectievelijk de kleinste werkgelegenheidsfluctuaties. Voor een compleet overzicht van de werkgelegenheidsfluctuaties per beroepsklasse wordt verwezen naar bijlage 1 .

4. Vgl. hiervoor de schattingsresultaten van de bezettingsgraad-variabele in het beroepenmode1 (Dekker, De Grip, Heijke 1988). 
Tabel 12a. Beroepsklassen met de grootste conjunctuurgevoeligheid (1950-1988)

\begin{tabular}{llc}
\hline code & beroepsklasse & Flb\% \\
\hline & & 38 \\
71 & Mijn-, groeve-arbeiders, boortechnici e.d. & 21 \\
95 & Metselaars, timmerlieden, e.a. bouwvakarbeiders & 19 \\
83 & Smeden, gereedschapsmakers e.d. & 19 \\
93 & Schilder e.d. & 18 \\
72 & Hoogovenarbeiders, walsers, gieters e.d. & 18 \\
87 & Loodgieters, pijpfitters, lasser e.d. & 17 \\
85 & Electromonteurs, -reparateurs & 17 \\
99 & Sjouwers, dokwerkers e.d. & 16 \\
70 & Leidinggevend produktiepersoneel & 16 \\
74 & Chemische procesarbeiders & \\
\hline
\end{tabular}

Bron: ROA

Tabel 12b. Beroepsklassen met de kleinste conjunctuurgevoeligheid (1950-1988)

\begin{tabular}{llc}
\hline code & beroepsklasse & FIb\% \\
\hline & & \\
61 & Zelfstandige land- en tuinbouwers & 4 \\
64 & Vissers, jagers & 4 \\
06 & Medisch- en paramedisch personeel & 5 \\
62 & Agrarische arbeiders & 5 \\
05 & Biologen, biochemici, landbouwkundigen e.d. & 6 \\
13 & Onderwijzend personeel & 6 \\
51 & Zelfstandige hotel-, restaurant-, caféhouders & 6 \\
57 & Kappers, schoonheidsspecialisten & 6 \\
59 & Diverse commerciële functies & 6 \\
60 & Bedrijfsleiders land- en tuinbouw & 6 \\
\hline
\end{tabular}

Bron: ROA

Bij de beroepen met de grootste conjunctuurgevoeligheid komen veel industriële beroepen voor, terwijl met name dienstverlenende beroepen relatief weinig conjunctuurgevoelig zijn.

\subsection{Uitwijkmogelijkheden}

Bij de indicator voor de uitwijkmogelijkheden maken we een onderscheid tussen de uitwijkmogelijkheden van opleidingen naar verschillende beroepen, van opleidingen naar bedrijfssectoren en van beroepen naar verschillende bedrijfssectoren. De idee om voor een opleiding een indicatie van de uitwijkmogelijkheden over de beroepen te bepalen sluit aan bij de opvatting dat er geen unieke koppeling bestaat tussen beroep en opleiding (Van Hoof en Dronkers, 1980). Aan de andere kant mag echter ook 
worden verwacht dat de mate van beroepsflexibiliteit tussen de verschillende opleidingen sterk kan uiteenlopen ${ }^{5}$.

De arbeidsmarktflexibiliteit van opleidingen en beroepen kan in kaart worden gebracht met behulp van spreidingsmaatstaven. Immers, hoe groter die spreiding, des te groter zal de flexibiliteit zijn op de arbeidsmarkt. Door Warnken (1986) is een matstaf ontwikkeld die een indicatie geeft van de bestaande flexibiliteit op de arbeidsmarkt: De 'Gini-Hirschman'-coëfficiënt. De formule voor de beroepenspreiding van opleidingstype 1 is als volgt:

$$
\mathrm{GH}_{1}=\left(1-\sum_{\mathrm{b}=1}^{\mathrm{B}} \mathrm{a}_{1 b^{2}}{ }^{2}\right) \cdot[\mathrm{B} /(\mathrm{B}-1)]
$$

waarin:

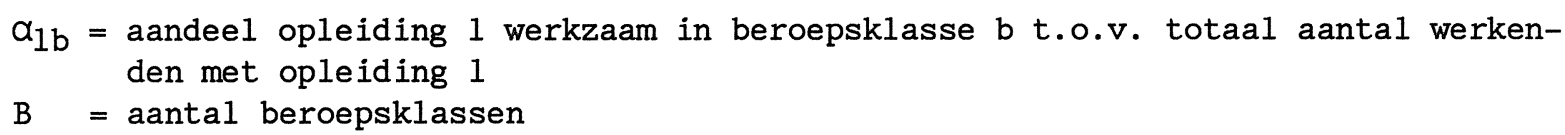

De indicator is gelijk aan 0 indien een opleiding slechts in één beroep voorkomt en gelijk aan 1 als de opleiding gelijkmatig over alle beroepen is verdeeld. Op soortgelijke wijze kunnen de formules voor de sectorspreiding van beroepen en opleidingen worden bepaald.

De interpretatie van de Gini-Hirschman coëfficiënt luidt naar analogie van de Ginicoëfficiënt als volgt. Er zijn een B-tal situaties waarin iemand zich kan bevinden. Als iemand een willekeurige nieuwe plaats krijgt toegewezen, getrokken uit de bestaande verdeling over alle mogelijke situaties, dan kan hij of zij weer in dezelfde situatie terecht komen of in een andere situatie. Dezelfde situatie heeft als 'opbrengst' 0 ; een andere situatie heeft als 'opbrengst' 1 . De Gini-Hirschman coëfficiënt geeft derhalve de gemiddelde kans om in een andere situatie terecht te komen.

Deze interpretatie wijst op drie belangrijke veronderstellingen bij de GiniHirschman coëfficiënt. Ten eerste wordt verondersteld dat het verschil tussen twee situaties altijd gelijk is. Ten tweede wordt verondersteld dat de opbrengst 0 is als men weer dezelfde situatie krijgt toegewezen. En ten derde dat er binnen één groep geen verschillen zijn. Wat het laatste betreft is derhalve ook het aggregatieniveau

5. Een verdere uitwerking van het belang van het combineren van arbeidsmarktprognoses met flexibiliteitsgegevens is te vinden in De Grip en Heijke (1989). 
waarop de spreidingsmaatstaf betrekking heeft van belang. Er wordt overigens in vergelijking 5 enigszins gecorrigeerd voor het aggregatieniveau door vermenigvuldiging met de term $[B /(B-1)]$.

In tabel 13a en $13 \mathrm{~b}$ worden de beroepen met de grootste en de kleinste sectorspreiding weergegeven. Met name bij leidinggevende en administratieve beroepen is de sectorspreiding groot. Beroepsklassen met een geringe branchespreiding betreffen met name de beroepen van zelfstandigen, die actief zijn in een bepaalde bedrijfssector en beroepsklassen die werkzaam zijn in de overheidssfeer. Een volledig overzicht van de branchespreiding per beroepsklasse is terug te vinden in bijlage 2 .

In tabel 14a en 14b worden respectievelijk de opleidingen met de hoogste en laagste beroepenspreiding weergegeven. De tabellen $15 \mathrm{a}$ en $15 \mathrm{~b}$ geven de hoogste en laagste sectorspreidingen per opleiding. In de bijlagen 3 en 4 worden de respectievelijke totaaloverzichten weergegeven.

Bij de spreiding van de opleidingstypen over de verschillende beroepsklassen kan worden vastgesteld dat de algemeen vormende opleidingen, zoals mocht worden verwacht, een grote beroepenspreiding hebben. Ook de technische en administratieve (lagere en middelbare) opleidingen blijken een grote beroepenspreiding te hebben. Enigszins bevreemdend is de hogere beroepenspreiding van de opleidingen die onder code 481 vallen: Uiterlijke verzorging, verzorging (MDGO), INTAS, maar hier kan worden opgemerkt dat onder deze opleidingen diverse zeer verschillende dienstverlenende opleidingen vallen (gezinsverzorging, kapper, KMBO verzorgende beroepen). Bij de opleidingen met een lage beroepenspreiding komen, naast een tweetal nietreguliere opleidingen, alleen opleidingen voor van middelbaar en hoger niveau. En ook hier zien we weer opleidingen die met name voor specifieke beroepen binnen de overheidssector opleiden.

Het geschetste beeld van de opleidingen met een hoge en met een lage sectorspreiding blijkt grotendeels overeen te stemmen met dat van de opleidingen met een extreme beroepenspreiding. Voor de opleidingen met een geringe spreiding zou men dit kunnen terugvoeren op het feit dat deze voor een specifiek beroep opleiden dat slechts in één sector voorkomt. Voor opleidingen met een grote sectorspreiding zijn er meerdere verklaringen mogelijk. Een opleiding kan in dat geval opleiden voor één beroep, dat echter in meer sectoren voorkomen, maar kan ook opleiden voor meer beroepen, die elk in een of in meer sectoren voorkomt. Om hiertussen enig onderscheid te kunnen aanbrengen moet men de sectorspreiding per opleiding in samenhang zien met de beroepenspreiding per opleiding. 
Tabel 13a. Beroepsklassen met de grootste bedrijfssectorspreiding (gemiddelde 1979-1985)

\begin{tabular}{llc}
\hline code & beroepsklasse & $\mathrm{GHb}$ \\
\hline & & \\
21 & Beleidvoerende en hogere leidinggevende functies & 0.96 \\
02 & Ingenieurs, tekenaars e.d. & 0.93 \\
32 & Secretaresses, (data)typistes e.d. & 0.93 \\
34 & Computerapparatuur-operateurs e.d. & 0.93 \\
97 & Laders, lossers, inpakkers e.d. & 0.93 \\
09 & Economen & 0.92 \\
39 & Diverse administratieve functies & 0.92 \\
70 & Leidinggevend produktiepersoneel & 0.92 \\
38 & Telefonisten, telegrafisten & 0.91 \\
84 & Instrumentmakers, monteurs e.d. & 0.91 \\
\hline
\end{tabular}

Bron: ROA

Tabel 13b. Beroepsklassen met de laagste bedrijfssectorspreiding (gemiddelde 1979-1985)

\begin{tabular}{llc}
\hline code & beroepsklasse & $\mathrm{GHb}$ \\
\hline & & \\
43 & Zelfstandige winkeliers & 0.00 \\
61 & Zelfstandige land- en tuinbouwers & 0.00 \\
40 & Directeuren en bedrijfsleiders groothandel & 0.01 \\
41 & Directeuren en bedrijfsleiders detailhandel & 0.01 \\
42 & Zelfstandige groothandelaren, tussenhandelaren & 0.01 \\
57 & Kappers, schoonheidsspecialisten & 0.07 \\
13 & Onderwijzend personeel & 0.09 \\
20 & Hogere leidinggevende functies bij openbaar bestuur & 0.09 \\
31 & Uitvoerende hoofdambtenaren & 0.12 \\
64 & Vissers, jagers & 0.14 \\
\hline
\end{tabular}

Bron: ROA

Tabel 14a. Opleidingstypen met de grootste beroepsklassespreiding (gemiddelde 1979-1985)

\begin{tabular}{llc}
\hline code & opleidingstype & $\mathrm{GH}$ \\
\hline & & \\
\hline 331 & Lager technisch onderwijs & 0.95 \\
436 & Middelbaar technisch onderwijs & 0.95 \\
301 & MAVO en HAVO, VwO (onderbouw) & 0.93 \\
441 & Middelbaar transport-, communicatie- en verkeersonderwijs & 0.93 \\
461 & Middelbare detailhandelschool en MEAO & 0.93 \\
401 & HAVO en VWO (bovenbouw) & 0.92 \\
361 & LEAO, LMO, kantoor/verkooppraktijk LHNO & 0.91 \\
381 & LHNO, excl. kantoor/verkooppraktijk & 0.91 \\
521 & Hoger agrarisch onderwijs & 0.91 \\
561 & HEAO, excl. bestuurlijke en fiscale richting & 0.90
\end{tabular}


Tabel 14b. Opleidingstypen met de laagste beroepsklassespreiding (gemiddelde 1979-1985)

\begin{tabular}{llc}
\hline code & opleidingstype & GHI \\
\hline & & 0.22 \\
651 & Medische wetenschappen & 0.26 \\
606 & Universitaire Lerarenopleiding, MO-B & 0.29 \\
551 & HBO-verpleegkunde, fysiotherapie, logopedie & 0.36 \\
454 & Opleiding ziekenverzorging e.d. & 0.37 \\
506 & PABO, nieuwe lerarenopleiding e.d. (NLO) & 0.41 \\
516 & Opleiding pastoraal werk e.d. & 0.42 \\
391 & Opleidingen bedrijfsbeveiliging en -bewaking & 0.49 \\
616 & Theologie (universitair) & 0.50 \\
652 & Farmacie, medische biologie e.d. & 0.51 \\
451 & Verpleegkunde en doktersassistente MDGO & \\
\hline
\end{tabular}

Bron: ROA

Tabel 15a. Opleidingstypen met de grootste bedrijfssectorspreiding (gemiddelde 1979-1985)

\begin{tabular}{llc}
\hline code & opleidingstype & $\mathrm{GH}_{\perp}$ \\
\hline & & \\
301 & MAVO en HAVO, VWO (onderbouw) & 0.94 \\
401 & HAVO en VWO (bovenbouw) & 0.94 \\
436 & Middelbaar technisch onderwijs & 0.94 \\
331 & Lager technisch onderwijs & 0.93 \\
361 & LEAO, LMO, kantoor/verkooppraktijk LHNO & 0.91 \\
431 & Middelbaar laboratoriumonderwijs (technisch) & 0.90 \\
531 & Hoger laboratoriumonderwijs (technisch) & 0.90 \\
381 & LHNO, excl. kantoor/verkooppraktijk & 0.89 \\
461 & Middelbare detailhandelschool en MEAO & 0.89 \\
636 & Technische wetenschappen & 0.88 \\
\hline
\end{tabular}

Bron: ROA

Tabel 15b. Opleidingstypen met de laagste bedrijfssectorspreiding (gemiddelde 1979-1985)

code opleidingstype $\quad$ GHI

\begin{tabular}{llc}
\hline & & 0.26 \\
606 & Universitaire Lerarenopleiding, MO-B & 0.26 \\
651 & Medische wetenschappen & 0.33 \\
506 & HBO-verpleegkunde, fysiotherapie, logopedie & 0.34 \\
466 & PABO, nieuwe lerarenopleiding (NLO) e.d. & 0.36 \\
516 & MEAO-bestuurlijke richting & 0.38 \\
552 & Opleiding pastoraal werk e.d. & 0.39 \\
451 & Verer laboratoriumonderwijs (medisch) & 0.41 \\
454 & Opleiding ziekenverzorging e.d. & 0.45 \\
483 & Middelbare horecaschool, kappersbedrijf & 0.46 \\
\hline
\end{tabular}


De tabellen met betrekking tot de uitwijkmogelijkheden overziend en gelet op de gevoeligheid van de indicator voor de mate van aggregatie, moet een relativerende opmerking worden gemaakt. Het blijkt namelijk dat de beroepen en opleidingen in de overheidssfeer wel goed onderscheiden kunnen worden, maar dat een aantal specialistische industriële of dienstenberoepen c.q. opleidingen toch niet in de tabel met lage spreidingsmatstaf voorkomen. De vermoedelijke reden is dat op het niveau van de 2-cijfer beroepsklasse-indeling overheidsberoepen als ambtenaar, leidinggevende bij openbaar bestuur, politie en leraar een aparte code hebben. De vraag rijst dus of de indeling op 2-cijferniveau onderscheidend genoeg is, of dat al een dermate hoge mate van aggregatie heeft plaats gevonden dat op beroepsklasse-niveau een te grove indeling is ontstaan.

Als we voor de beroepen de spreidingsmaatstaf met de conjunctuurgevoeligheid combineren dan zien we voor bijvoorbeeld onderwijzend personeel in tabel $13 \mathrm{~b}$ een $\mathrm{kleine}$ sectorspreiding, maar ook een geringe conjunctuurgevoeligheid (tabel 12b). Dit voorbeeld geeft aan dat men deze indicatoren, zoals in I-See! inderdaad gebeurt, in samenhang met elkaar (en met de prognoses) moet bezien. 


\section{BESLUIT}

Ten aanzien van de gemaakte middellange-termijn prognoses hebben er ten opzichte van de rapportage uit 1987 een aantal verbeteringen plaats gevonden. De gebruikte modellen hebben een betere theoretische onderbouwing gekregen. Voor de opleidingen is bovendien ditmaal voor het eerst een volledig overzicht van de arbeidsmarkt geconstrueerd. De dataproblemen blijven echter nog steeds actueel waardoor de prognoseperiode 1985-'92 moest worden gehandhaafd. De korte waarnemingsperiode leidde er toe dat er bij het schatten van de modellen gebruik moest worden gemaakt van pooling van data, zonder dat de stabiliteit van de parameters in de tijd en over de bedrijfssectoren adequat kon worden onderzocht. Verder lijkt de gebruikte classificatie van met name de beroepsklassen nogal eens niet overeen te komen met de feitelijk bestaande arbeidsmarktsegmenten.

Voor het vervolledigen van het informatiesysteem lijkt de gevolgde twee-sporen aanpak, van begin af aan prognoses maken en gelijktijdig komen tot betere gegevens en modellen, een vruchtbare aanpak. Zo kon een deel van de informatie direct worden opgenomen in I-See!. De koppeling aan I-See! maakt het mogelijk om bij de verdere ontwikkeling van het ROA-informatiesysteem rekening te houden met wensen van de gebruikers, met betrekking tot zowel de inhoud als de vormgeving van de arbeidsmarktinformatie.

Op het traject van de methodische uitbouw zijn modellen voor de prognose van de uitbreidingsvraag naar beroepsklasse en opleidingstype ontwikkeld en toegepast. Het onderzoek naar econometrisch consistente modellen voor de prognose van de uitbreidingsvraag, waarbij rekening wordt gehouden met speciale eisen als gevolg van dataen econometrische restricties wordt voortgezet. In dat verband zal ook de invloed van de arbeidsduur op de beroepenstructuur explicieter in het beroepenmodel worden opgenomen (zie Groot en Heijke 1989). Ook de modellering van de vervangingsvraag zal worden verbeterd. Voor de vervangingsvraag zijn reeds additionele data verzameld, hoewel het niet mogelijk is om hiervoor meer recente gegevens uit de Enquête Beroepsbevolking (EBB) te verkrijgen. Voor een betere modellering van de werkgelegenheid in beroepsklassen kan wellicht wel gebruik worden gemaakt van EBBgegevens al lijkt hier sprake te zijn van een trendbreuk ten opzichte van de gegevens uit de Arbeidskrachtentellingen.

De prognoseperiode zal, indien er zich geen restricties als gevolg van dataproblemen voordoen, met ingang van 1991 worden verlegd naar de periode 1990-1994. Voor de beroepen zal dan worden nagegaan of een nieuwe classificatie, die beter aansluit bij 
de bestaande arbeidsmarktsegmenten, kan worden geïmplementeerd. Bij de uitbouw van het informatiesysteem zal ook verder worden gezocht naar nieuwe arbeidsmarktindicatoren en zal worden nagegaan of een verdere regionalisering van de informatie haalbaar is. 


\section{LITERATUUR}

Beekman, Th.B.J., R.J.P. Dekker, A. de Grip, J.A.M. Heijke (1989), Een verklaring van de opleidingenstructuur van beroepen, ROA-W-1989/3, Maastricht.

Bureau of Labor Statistics (1988), Occupational outlook quarterly, Vol. 32, Nr. 2, U.S. Department of Labor, Washington D.C.

Centraal Bureau voor de Statistiek (1985), Beroepenclassificatie 1984, Voorburg.

Centraal Bureau voor de Statistiek (1986), Standaard Onderwijs Indeling 1978, Voorburg.

Centraal Planbureau (1989), Centraal Economisch Plan, 's-Gravenhage.

Centraal Planbureau (1989), Macro Economische Verkenning 1990, waarin opgenomen een macro-economische verkenning voor de periode 1991-1994, 's-Gravenhage.

Dekker, R.J.P., A. de Grip, J.A.M. Heijke (1988), Een verklaring van de beroepenstructuur van bedrijfstakken, ROA-W-1988/2, Maastricht.

Grip, A. de, (1987), Onderwijs en Arbeidsmarkt: Scholingsdiscrepanties, VUuitgeverij, Amsterdam.

Grip, A. de, J.A.M. Heijke (1988), Arbeidsmarktindicatoren: een inventarisatie, ROAW-1988/1, Maastricht.

Grip, A. de, L.F.M. Groot, J.A.M. Heijke (1987), Clustering occupational classes by educational structure, ROA-W-1987/2E, Maastricht.

Grip, A. de, J.A.M. Heijke (1989), Het flexibiliteitspotentieel van universitaire studierichtingen, Tijdschrift voor Arbeidsvraagstukken, jaargang $5 \mathrm{nr}$. 4, pp. 6981 .

Grip, A. de, J.A.M. Heijke, R.J.P. Dekker, L.F.M. Groot (1987), De arbeidsmarkt naar beroep in 1992 en de positie van academici daarbinnen, ROA-W-1987/1, Maastricht.

Grip, A. de, J.A.M. Heijke, R.J.P. Dekker, Th.B.J. Beekman, H.M.M. Peeters (1989), De arbeidsmarktperspectieven van beroepsklassen en opleidingstypen in 1992, rapportage I-See!, ROA-R-1989/7, Maastricht.

Groot, L.F.M., J.A.M. Heijke, (1989), Een verklaring van arbeidsduur en deeltijdarbeid naar beroep en bedrijfstak, ROA-W-1989/2, Maastricht.

Hoof, J.J. van, J. Dronkers (1980), Onderwijs en arbeidsmarkt; een verkenning van de relaties tussen onderwijs, arbeidsmarkt en arbeidssysteem, Van Loghum Slaterus, Deventer.

Kuhry, B., H.E. Ruitenberg, R.M. Spronk (1986), De onderwijsprognose 1986. Leerlingen, schoolverlaters en bevolking naar opleidingsniveau tot 2000. (SKILL), Werkdocument 9, Centraal Planbureau, 's-Gravenhage.

Nederlands Economisch Instituut (1972), Bouwnijverheid: planning, groei en fluctuaties, deel II: fluctuaties, Rotterdam.

ROA (1989), Naar een informatiesysteem onderwijs-arbeidsmarkt, onderzoeksprogramma 1989/1990, ROA-R-1989/1, Maastricht. 
Ruitenberg, H.E. (1989), Tijdreeksen uit de onderwijsprognoses 1989-1, Centraal Planbureau, Hoofdafdeling II, Afdeling Arbeid, Notitienummer 15, 's-Gravenhage.

Taakgroep Studentenramingen (1988), Wetenschappelijke Onderwijs Ramingen Studenten Aantallen (WORSA 1988), 's-Gravenhage.

Taakgroep Studentenramingen (1988), Raming Hoger Beroepsonderwijs Studentenaantallen (RHOBOS 1988), 's-Gravenhage.

Warnken, J. (1986), Zur Entwicklung der 'Internen" Anpassungfähigkeit der Berufe bis zum Jahre 2000. Projektionen unter den Annahmen der Wachstumszenarien der Prognos-Studie, Mitteilingen aus der Arbeitsmarkt- und Berufsforschung, nr. 1 , pp. 119-133. 
BIJLAGE 1. Totaaloverzicht van de conjunctuurgevoeligheid per beroepsklasse (Fluktuatie-index FI)

$\begin{array}{lll}\text { Code Nam } & \text { FI }\end{array}$

$01 \quad$ Schei-, natuurkundigen e.a. technici

$02 \quad$ Ingenieurs, tekenaars e.d. $\quad 13.6$

$04 \quad$ Vliegtuig- en scheepsofficieren 13.5

05 Bioloog, biochemicus, landbouwkundige $\quad 6.3$

$06 \quad$ Medisch-en paramedisch personeel $\quad 5.4$

$08 \quad$ Wiskundigen, systeemanalisten e.d.

$09 \quad$ Econoom $\quad 9.1$

11 Accountant, belastingconsulent $\quad 6.8$

$\begin{array}{lll}12 & \text { Jurist, notaris, rechter } & 7.2\end{array}$

13 Onderwijzend personeel $\quad 6.5$

14 Theoloog, dominee, pastor e.d.

15 Journalist, auteur, redacteur e.d.

$16 \quad$ Kunstenaar, ontwerper, fotograaf filmer $\quad 8.0$

17 Musicus, dirigent, toneelspeler e.d.

18 Beroepssporter, trainer, sportleraar 7.0

$19 \quad$ Sociale hulpverleners, vertalers e.d.

$20 \quad$ Hogere leid. functies bij openb. bestuur $\quad 6.6$

$21 \quad$ Beleidvoerende en hogere leid. functies 12.9

$30 \quad$ Leidinggevend administratief personeel $\quad 9.0$

$\begin{array}{lll}31 & \text { Uitvoerend hoofdambtenaar } & 6.7\end{array}$

32 Secretaresse, typist, datatypist e.d. $\quad 9.0$

$33 \quad$ Bankemployé, lokettisten e.d.

34 Computerapparatuur-operateurs e.d. $\quad 10.1$

$35 \quad$ Leidinggevend personeel transportbedrijf $\quad 11.1$

$36 \quad$ Conducteur $\quad 10.4$

$37 \quad$ Postsorteerder, postbesteller e.d. $\quad 9.9$

$38 \quad$ Telefonist, telegrafist $\quad 9.6$

$39 \quad$ Diverse administratieve functies $\quad 9.3$

$\begin{array}{lll}40 & \text { Directeur en bedrijfsleider groothandel } & 6.8\end{array}$

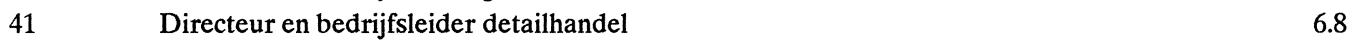

$\begin{array}{lll}42 & \text { Zelfst. groothandelaar, tussenhandelaar } & 6.8\end{array}$

$43 \quad$ Zelfstandige winkelier niet in winkel $\quad 6.8$

$45 \quad$ Verkoopchef, filiaalhouder, inkoper e.d. $\quad 9.1$

$46 \quad$ Vertegenwoordiger $\quad 9.1$

$47 \quad$ Verzekeringsagenten, makelaars e.d. $\quad 10.2$

$48 \quad$ Winkelbediende, marktverkoper e.d.

50 Directeur/bedrijfsleider horecabedrijf $\quad 8.4$

$51 \quad$ Zelfstandig hotel-, rest.-, caféhouder $\quad 6.3$

\begin{tabular}{ll}
52 & Leidinggevend huishoudelijk personeel \\
\hline
\end{tabular}

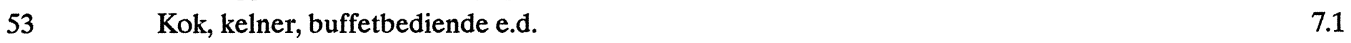

$54 \quad$ Huishoudelijk- en verzorgend personeel $\quad 7.0$

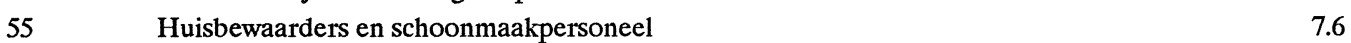

56 Wasser, perser $\quad 7.0$

$57 \quad$ Kapper, schoonheidsspecialist $\quad 6.3$

$\begin{array}{lll}58 & \text { Brandweer-, politiepersoneel, bewakers } & 7.4\end{array}$

$\begin{array}{ll}59 & \text { Diverse commerciele functies } \\ 60.4\end{array}$

$\begin{array}{ll}60 & \text { Bedrijfsleider land- en tuinbouw } \\ 6.1\end{array}$

$61 \quad$ Zelfstandige land- en tuinbouwers $\quad 3.8$

$62 \quad$ Agrarische arbeiders $\quad 5.4$

$63 \quad$ Boswachter en bosarbeider $\quad 8.1$

$64 \quad$ Visser, jager $\quad 4.3$

$70 \quad$ Leidinggevend produktiepersoneel 15.8

$71 \quad$ Mijn-, groeve-arbeider, boortechnicus 37.6

72 Hoogovenarbeiders, walsers, gieters e.d. 18.3

73 Houtzager, papiermaker $\quad 10.9$

$74 \quad$ Chemische procesarbeiders $\quad 15.9$

75 Spinners, wevers, ververs e.d. 16.2 
Kleermakers, stoffeerders e.d.

Schoenmaker, ledermaker

Meubelmaker en andere houtbewerkers $\quad 14.6$

$\begin{array}{ll}\text { Smeden, gereedschapsmakers e.d. } & 18.8\end{array}$

Instrumentmakers, monteurs e.d. $\quad 12.5$

Electromonteurs, -reparateurs $\quad 17.5$

$\begin{array}{lr}\text { Geluids-, beeldapparatuurbedieners } & 7.0\end{array}$

Loodgieter, pijpfitter, lasser e.d. $\quad 17.8$

Goud- en zilversmeden, diamantbewerker $\quad 12.9$

Glas-, aardewerkvormer e.d. functies $\quad 15.0$

Rubber-, plasticproduktenmaker $\quad 14.0$

Papierwaren-, kartonnagewerker $\quad 11.2$

Drukker en verwante functies $\quad 11.5$

$\begin{array}{ll}\text { Schilder e.d. } & 19.1\end{array}$

Ambachts- en industrieberoepen n.e.g. $\quad 14.0$

Metselaar, timmerman, e.a. bouwvakkers $\quad 21.0$

Machinisten e.a. bedieners van machines $\quad 11.5$

Laders, lossers, inpakkers e.d. $\quad 11.6$

Chauffeurs, matrozen, treinbestuurders $\quad 10.2$

Sjouwers, dokwerkers e.d. $\quad 17.3$ 
BIJLAGE 2. Totaaloverzicht van de bedrijfssectorspreiding per beroepsklasse (Gini-Hirschman coëfficiënt GH)

\begin{tabular}{lll}
\hline Code $\quad$ Naam & GH \\
\hline
\end{tabular}

01

Schei-, natuurkundigen e.a. technici

Ingenieurs, tekenaars e.d.

Vliegtuig- en scheepsofficieren

Bioloog, biochemicus, landbouwkundige

Medisch- en paramedisch personeel

Wiskundigen, systeemanalisten e.d.

Econoom

Accountant, belastingconsulent

Jurist, notaris, rechter

Onderwijzend personeel

Theoloog, dominee, pastor e.d.

Journalist, auteur, redacteur e.d.

Kunstenaar, ontwerper, fotograaf filmer

Musicus, dirigent, toneelspeler e.d.

Beroepssporter, trainer, sportleraar

Sociale hulpverleners, vertalers e.d.

Hogere leid. functies bij openb. bestuur

Beleidvoerende en hogere leid. functies

Leidinggevend administratief personeel

Uitvoerend hoofdambtenaar

Secretaresse, typist, datatypist e.d.

Bankemployé, lokettisten e.d.

Computerapparatuur-operateurs e.d.

Leidinggevend personeel transportbedrijf

Conducteur

Postsorteerder, postbesteller e.d.

Telefonist, telegrafist

Diverse administratieve functies

Directeur en bedrijfsleider groothandel

Directeur en bedrijfsleider detailhandel

Zelfst. groothandelaar, tussenhandelaar

Zelfstandige winkelier

Verkoopchef, filiaalhouder, inkoper e.d.

Vertegenwoordiger

Verzekeringsagenten, makelaars e.d.

Winkelbediende, marktverkoper e.d.

Directeur/bedrijfsleider horecabedrijf

Zelfstandig hotel-, rest.-, caféhouder

Leidinggevend huishoudelijk personeel

Kok, kelner, buffetbediende e.d.

Huishoudelijk- en verzorgend personeel

$\begin{array}{ll}\text { Huisbewaarders en schoonmaakpersoneel } & 0.79\end{array}$

Wasser, perser

$\begin{array}{ll}\text { Kapper, schoonheidsspecialist } & 0.07\end{array}$

$\begin{array}{ll}\text { Brandweer-, politiepersoneel, bewakers } & 0.41\end{array}$

$\begin{array}{ll}\text { Diverse commerciele functies } & 0.65\end{array}$

Bedrijfsleider land- en tuinbouw $\quad 0.43$

$\begin{array}{ll}\text { Zelfstandige land- en tuinbouwers } & 0.00\end{array}$

$\begin{array}{ll}\text { Agrarische arbeiders } & 0.31\end{array}$

$\begin{array}{ll}\text { Boswachter en bosarbeider } & 0.57\end{array}$

Visser, jager $\quad 0.14$

Leidinggevend produktiepersoneel $\quad 0.92$

$\begin{array}{ll}\text { Mijn-, groeve-arbeider, boortechnicus } & 0.62\end{array}$

Hoogovenarbeiders, walsers, gieters e.d. $\quad 0.65$

\begin{tabular}{ll} 
Houtzager, papiermaker & 0.52 \\
\hline
\end{tabular}

$\begin{array}{ll}\text { Chemische procesarbeiders } & 0.52\end{array}$ 
$\begin{array}{ll}\text { Tabakbewerker, tabakpoduktenmaker } & 0.01\end{array}$

$\begin{array}{ll}\text { Kleermakers, stoffeerders e.d. } & 0.70\end{array}$

$\begin{array}{ll}\text { Schoenmaker, ledermaker } & 0.52\end{array}$

$\begin{array}{ll}\text { Meubelmaker en andere houtbewerkers } & 0.53\end{array}$

$\begin{array}{ll}\text { Smeden, gereedschapsmakers e.d. } & 0.58\end{array}$

$\begin{array}{ll}\text { Instrumentmakers, monteurs e.d. } & 0.91\end{array}$

$\begin{array}{ll}\text { Electromonteurs, -reparateurs } & 0.88\end{array}$

$\begin{array}{ll}\text { Geluids-, beeldapparatuurbedieners } & 0.56\end{array}$

$\begin{array}{ll}\text { Loodgieter, pijpfitter, lasser e.d. } & 0.80\end{array}$

$\begin{array}{ll}\text { Goud- en zilversmeden, diamantbewerker } & 0.51\end{array}$

$\begin{array}{ll}\text { Glas-, aardewerkvormer e.d. functies } & 0.35\end{array}$

$\begin{array}{ll}\text { Rubber-, plasticproduktenmaker } & 0.34\end{array}$

$\begin{array}{ll}\text { Papierwaren-, kartonnagewerker } & 0.23\end{array}$

$\begin{array}{ll}\text { Drukker en verwante functies } & 0.49\end{array}$

$\begin{array}{ll}\text { Schilder e.d. } & 0.54\end{array}$

$\begin{array}{ll}\text { Ambachts- en industrieberoepen n.e.g. } & 0.85\end{array}$

$\begin{array}{ll}\text { Metselaar, timmerman, e.a. bouwvakkers } & 0.28\end{array}$

$\begin{array}{ll}\text { Machinisten e.a. bedieners van machines } & 0.87\end{array}$

$\begin{array}{ll}\text { Laders, lossers, inpakkers e.d. } & 0.93\end{array}$

Chauffeurs, matrozen, treinbestuurders $\quad 0.68$

$\begin{array}{lr}\text { Sjouwers, dokwerkers e.d. } & 0.72\end{array}$ 
BIJLAGE 3. Totaaloverzicht van de beroepsklassespreiding per opleidingstype (Gini-Hirschman coëfficiënt GH)

\begin{tabular}{lll}
\hline Code $\quad$ Naam & GH
\end{tabular}

\begin{tabular}{|c|c|c|}
\hline 301 & MAVO en HAVO, VWO (onderbouw) & 0.93 \\
\hline 321 & Lager agrarisch onderwijs & 0.74 \\
\hline 331 & Lager technisch onderwijs & 0.95 \\
\hline 341 & Lager transport-, comm.- en verkeersonderwijs & 0.78 \\
\hline 351 & Lager medisch en paramedisch onderwijs & 0.80 \\
\hline 361 & LEAO, LMO, Kantoor/verkooppraktijk LHNO & 0.91 \\
\hline 381 & LHNO, excl. kantoor/verkooppraktijk & 0.91 \\
\hline 391 & Opl. bedrijfsbeveiliging en -bewaking & 0.42 \\
\hline 401 & HAVO en VWO & 0.92 \\
\hline 406 & Opleidingen rij-instructeur, sportleider & 0.70 \\
\hline 421 & Middelbaar agrarisch onderwijs & 0.76 \\
\hline 431 & Middelbaar laboratoriumonderwijs & 0.80 \\
\hline 436 & Middelbaar technisch onderwijs & 0.95 \\
\hline 441 & Mid. transport-, comm.- en verkeersonderwijs & 0.93 \\
\hline 451 & Verpleegkunde en doktersassistente MDGO & 0.51 \\
\hline 452 & Mid. laboratoriumonderwijs (medisch) & 0.67 \\
\hline 453 & Opleiding medisch secretaresse e.d. & 0.63 \\
\hline 454 & Opleiding ziekenverzorging e.d. & 0.36 \\
\hline 461 & Middelbare detailhandelschool en MEAO & 0.93 \\
\hline 466 & MEAO-bestuurlijke richting & 0.75 \\
\hline 471 & Sociale arbeid en agogisch werk (MDGO) & 0.82 \\
\hline 481 & Uit. verzorging, verzorging MDGO, INTAS & 0.86 \\
\hline 483 & Middelbare horecaschool, kappersbedrijf & 0.82 \\
\hline 486 & Modetekenen e.d. & 0.84 \\
\hline 506 & PABO, Nieuwe Lerarenopleiding e.d. & 0.37 \\
\hline 511 & Tolk- en vertalersopleidingen & 0.85 \\
\hline 516 & Opleiding pastoraal werk e.d. & 0.41 \\
\hline 521 & Hoger agrarisch onderwijs & 0.91 \\
\hline 531 & Hoger laboratorium onderwijs & 0.77 \\
\hline 536 & Hoger technisch onderwijs & 0.70 \\
\hline 541 & Hoger transport-, comm.- en verkeersonderwijs & 0.86 \\
\hline 551 & HBO-verpleegkunde, fysiotherapie & 0.29 \\
\hline 552 & Hoger laboratoriumonderwijs (medisch) & 0.67 \\
\hline 554 & Opleiding diëtetiek e.d. & 0.55 \\
\hline 561 & HEAO, excl. bestuurl. en fiscale richting & 0.90 \\
\hline 562 & Arbeidsanalist, bedrijfskunde (HTS) e.d. & 0.84 \\
\hline 566 & HEAO, juridische en bestuurl. richting & 0.88 \\
\hline 571 & Sociale academie, Bibliotheekacademie & 0.64 \\
\hline 583 & Hogere Hotelschool & 0.89 \\
\hline 586 & Kunstacademie, toneelschool & 0.78 \\
\hline 606 & Universitaire Lerarenopleiding, MO-B & 0.26 \\
\hline 611 & Letteren (universitair) & 0.52 \\
\hline 616 & Theologie (universitair) & 0.49 \\
\hline 621 & Agrarische wetenschappen & 0.82 \\
\hline 631 & Wiskunde en natuurwetenschappen & 0.82 \\
\hline 636 & Technische wetenschappen & 0.68 \\
\hline 651 & Medische wetenschappen & 0.22 \\
\hline 652 & Farmacie, Medische biologie e.d. & 0.50 \\
\hline 661 & Economie, bedrijfsk. (drs.), informatica & 0.86 \\
\hline 662 & Bedrijfsk. (ir), econometrie en actuariaat & 0.80 \\
\hline 666 & Rechtsgeleerdheid en bestuurskunde & 0.70 \\
\hline 671 & Sociale wetenschappen & 0.66 \\
\hline 686 & Kunstwetenschappen & 0.79 \\
\hline
\end{tabular}


BIJLAGE 4. Totaaloverzicht van de bedrijfssectorspreiding per opleidingstype (Gini-Hirschman coëfficiënten GH)

\begin{tabular}{lll}
\hline Code Naam & GH \\
\hline
\end{tabular}

\begin{tabular}{|c|c|c|}
\hline 301 & MAVO en HAVO, VWO (onderbouw) & 0.94 \\
\hline 321 & Lager agrarisch onderwijs & 0.58 \\
\hline 331 & Lager technisch onderwijs & 0.93 \\
\hline 341 & Lager transport-, comm.- en verkeersonderwijs & 0.78 \\
\hline 351 & Lager medisch en paramedisch onderwijs & 0.63 \\
\hline 361 & LEAO, LMO, Kantoor/verkooppraktijk LHNO & 0.91 \\
\hline 381 & LHNO, excl. kantoor/verkooppraktijk & 0.89 \\
\hline 391 & Opl. bedrijfsbeveiliging en -bewaking & 0.77 \\
\hline 401 & HAVO en VWO & 0.94 \\
\hline 406 & Opleidingen rij-instructeur, sportleider & 0.57 \\
\hline 421 & Middelbaar agrarisch onderwijs & 0.55 \\
\hline 431 & Middelbaar laboratoriumonderwijs & 0.90 \\
\hline 436 & Middelbaar technisch onderwijs & 0.94 \\
\hline 441 & Mid. transport-, comm.- en verkeersonderwijs & 0.79 \\
\hline 451 & Verpleegkunde en doktersassistente MDGO & 0.41 \\
\hline 452 & Mid. laboratoriumonderwijs (medisch) & 0.69 \\
\hline 453 & Opleiding medisch secretaresse e.d. & 0.49 \\
\hline 454 & Opleiding ziekenverzorging e.d. & 0.45 \\
\hline 461 & Middelbare detailhandelschool en MEAO & 0.89 \\
\hline 466 & MEAO-bestuurlijke richting & 0.36 \\
\hline 471 & Sociale arbeid en agogisch werk (MDGO) & 0.80 \\
\hline 481 & Uit. verzorging, verzorging MDGO, INTAS & 0.83 \\
\hline 483 & Middelbare horecaschool, kappersbedrijf & 0.46 \\
\hline 486 & Modetekenen e.d. & 0.80 \\
\hline 506 & PABO, Nieuwe Lerarenopleiding e.d. & 0.34 \\
\hline 511 & Tolk- en vertalersopleidingen & 0.80 \\
\hline 516 & Opleiding pastoraal werk e.d. & 0.38 \\
\hline 521 & Hoger agrarisch onderwijs & 0.87 \\
\hline 531 & Hoger laboratorium onderwijs & 0.90 \\
\hline 536 & Hoger technisch onderwijs & 0.94 \\
\hline 541 & Hoger transport-, comm.- en verkeersonderwijs & 0.85 \\
\hline 551 & HBO-verpleegkunde, fysiotherapie & 0.33 \\
\hline 552 & Hoger laboratoriumonderwijs (medisch) & 0.39 \\
\hline 554 & Opleiding diëtetiek e.d. & 0.55 \\
\hline 561 & HEAO, excl. bestuurl. en fiscale richting & 0.94 \\
\hline 562 & Arbeidsanalist, bedrijfskunde (HTS) e.d. & 0.81 \\
\hline 566 & HEAO, juridische en bestuurl. richting & 0.68 \\
\hline 571 & Sociale academie, Bibliotheekacademie & 0.75 \\
\hline 583 & Hogere Hotelschool & 0.70 \\
\hline 586 & Kunstacademie, toneelschool & 0.74 \\
\hline 606 & Universitaire Lerarenopleiding, MO-B & 0.26 \\
\hline 611 & Letteren (universitair) & 0.35 \\
\hline 616 & Theologie (universitair) & 0.48 \\
\hline 621 & Agrarische wetenschappen & 0.78 \\
\hline 631 & Wiskunde en natuurwetenschappen & 0.66 \\
\hline 636 & Technische wetenschappen & 0.88 \\
\hline 651 & Medische wetenschappen & 0.26 \\
\hline 652 & Farmacie, Medische biologie e.d. & 0.65 \\
\hline 661 & Economie, bedrijfsk. (drs.), informatica & 0.86 \\
\hline 662 & Bedrijfsk. (ir), econometrie en actuariaat & 0.80 \\
\hline 666 & Rechtsgeleerdheid en bestuurskunde & 0.73 \\
\hline 671 & Sociale wetenschappen & 0.67 \\
\hline 686 & Kunstwetenschappen & 0.65 \\
\hline
\end{tabular}

